\title{
Operating Leverage Analysis - A Conceptual Framework
}

\author{
Sandip Sinha \\ Department of Commerce, Dwijendralal College (Affiliated to the University of Kalyani), \\ Krishnagar, Nadia, West Bengal, India .
}

\begin{abstract}
A conceptual framework for intra-firm operating leverage analysis \{ based on the mechanical analysis of physical leverage ( the genesis of the concept of operating leverage) \} of a manufacturing firm under condition of future business risk considering a short-term planning horizon, composed of (a) an ex-ante analysis conducted at the beginning of the period for choosing an 'Operating Account Structural Plan' (OASP) from alternative OASPs based on the principle of maximization of expected utility $\{$ or principle of minimization of absolute value of expected disutility (negative utility)\} of the 'elasticity coefficient measure' of the 'Degree of Operating Leverage '( DOL ) considering the degrees of 'Downside Operating Leverage Risk (DOLR) Averseness' and 'Upside Operating Leverage Risk (UOLR ) Affinity' subjectively assigned by the decision-maker, and (b) an ex-post analysis conducted at the end of the period for the performance appraisal of the decision-maker based on 'operating leverage efficiency', is formulated and illustrated in this working paper.
\end{abstract}

Keywords : Physical Leverage, Operating Leverage, Operating Account Structural Plan, Degree of Operating Leverage, Operating Leverage Risk, Downside Operating Leverage Risk, Upside Operating Leverage Risk, Coefficient of Variation, Mean Absolute Deviation, Operating Leverage Efficiency.

\section{Introduction}

The term 'leverage' literally means 'the power to influence'. The concept of 'operating leverage' [ a type of 'business leverage' ] has been derived from the concept of 'physical leverage'. 1.1 CONCEPT OF PHYSICAL LEVERAGE

In physics, leverage refers to the mechanics of a lever. A lever is a simple machine that can magnify an applied effort ( effort force) to overcome a resistance (load) by generating a magnified force ( load force) by turning about a fixed point called the fulcrum .

The mechanical advantage ( M A ) of a lever is the factor by which it multiplies the effort force. There are two types of mechanical advantage (MA):

(a) Ideal ( or theoretical) mechanical advantage ( I M A), and

(b) Actual mechanical advantage ( AMA) .

The ideal mechanical advantage of a lever is the mechanical advantage it would have in the absence of friction or any other means that can waste useful energy and it sets an upper limit on achievable performance of the lever.

The IM A of a lever is given by : IM A = (Effort arm / Load arm $)$

where, effort arm $=$ the perpendicular distance of the effort force from the fulcrum , and

load $\operatorname{arm}=$ the perpendicular distance of the load force from the fulcrum .

Thus the relative position of the fulcrum with respect to the effort and load forces affects the degree of I M A.

Physical leverage is ideally said to exist when IMA > 1, i.e. when Effort arm > Load arm, i .e. when the fulcrum is closer to the load than that to the effort. This happens in the cases of Class I (where the fulcrum is in between the effort and the load) and Class II (where the load is in between the effort and the fulcrum ) levers .

Physical leverage is ideally not said to exist even in the presence of the fulcrum when IMA $\leq 1$, i.e when Effort arm $\leq$ Load arm , i.e. when the fulcrum is equidistant from the effort and the load or when the fulcrum is closer to the effort than that to the load .

The actual mechanical advantage is the mechanical advantage taking into consideration real world factors such as energy lost by friction and other factors .

The AMA of a lever is given by :

A M A = ( Actual magnitude of load force / Actual magnitude of effort force $)$

A M A > 1 for Class I and Class II levers only when the fulcrum is closer to the load than that to the effort .

Now, the 'law of lever' [ based on the principle of linear moments] states that in static equilibrium with the forces balancing and in the absence of friction and other factors wasting useful 
energy, the ideal ( or expected) work output [ the product of the ideal ( or expected ) magnitude of the load force and the load arm] will be equal to the ideal (or expected) work input [ the product of the ideal (or expected) magnitude of the effort force and the effort arm ] .

Mathematically, Expected work output $=$ Expected work input , or

Expected magnitude of load force $*$ Load arm $=$ Expected magnitude of effort force $*$

Effort arm or Expected magnitude of load force $=$ I M A * Expected magnitude of effort force

From eq. ( 3 ) we get :

IMA = [ Expected magnitude of load force / Expected magnitude of effort force ]

The following diagram ( based on Class I lever) illustrates the concept of physical leverage. Fulcrum

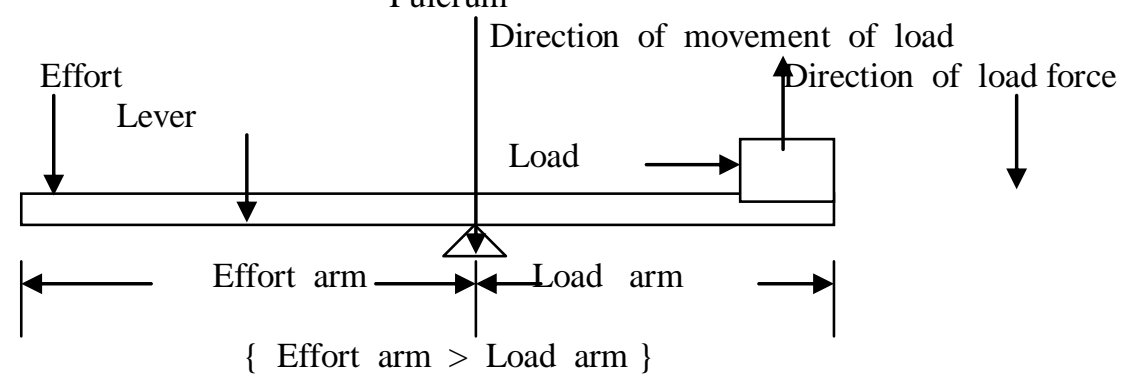

[ Figure 1]

Now, in the real world, due to the presence of friction and other factors wasting useful energy, Actual useful work output $<$ actual work input, or

Actual magnitude of load force * Load arm < Actual magnitude of effort force * Effort arm,

or AM A $<$ IM A.

The efficiency of a lever measures the degree to which friction and other factors reduce the actual work output of the machine from its theoretical maximum and may be calculated as : Efficiency $=($ Actual useful work output $/$ Actual work input $) * 100 \%$

or Efficiency $=($ A M A / I M A $) * 100 \%$

\subsection{MECHANICAL ANALYSIS OF A PHYSICAL LEVER}

The mechanical analysis ( based on the principle of linear moments) of a physical lever in a physics laboratory may be said to involve the following steps :

(a) calculating the IMA of the lever vide eq.(1) for a particular relative position ( with respect to the load and the effort forces ) of the physical fulcrum (PF) ;

(b) formulating a linear functional relationship between the expected magnitude of the load force $\{$ dependent physical variable (DPV) $\}$ and the expected magnitude of the effort force $\{$ independent physical variable ( I PV ) \} as per eq. (3), I M A \{calculated vide eq.( 1 ) in step (a) \} remaining constant ;

(c) actually applying effort force, observing the generated load force and calculating the A M A of the lever vide eq. (2);

(d) calculating the efficiency of the lever vide eq. (5); and

(e) repeating steps (a) to (d) considering mutually dependent alternative physical scenarios of the physical fulcrum (PF) with its varying relative position.

\subsection{OBJECTIVE OF THE STUDY}

A voluminous amount of discussions regarding various aspects of operating leverage exist in managerial accounting and finance literatures which nevertheless lack a thorough and conceptual analysis of operating leverage based on the concept of physical leverage (the genesis of the concept of operating leverage). The fundamental informational needs for operating leverage analysis [ where 'Earnings Before Interest and Tax (EBIT) \{ or operating earnings \} is considered as the 'dependent financial variable' (DFV) and sales as the 'independent financial variable' (IFV)] are the data on quantity of sales, selling price per unit, variable operating cost per unit and fixed operating cost. Such information can only be obtained from the internal managerial accounting information system of the firm. Externally published financial statements do not contain the whole gamut of such information. Operating leverage analysis can thus be conducted judiciously and effectively by a managerial personnel having access to such information (intra-firm analysis ) and any other analyses conducted by an external agent (without any access to holistic managerial accounting information) based on the published financial statements is bound to be unjustified and ineffective. The objective 
Operating Leverage Analysis - A Conceptual Framework

of this study is to formulate and elucidate a conceptual framework for 'intra - firm analysis' ${ }^{1}$ of operating leverage [based on the mechanical analysis of 'physical leverage'] in respect of a manufacturing firm in the short run $^{2}$ under condition of future business risk.

\section{Operating Leverage}

\section{CONCEPT OF OPERATING LEVERAGE}

Two definitions of operating leverage are cited below:

(A ) "Operating leverage is concerned with a company's cost structure and deals with the relationship between sales and operating profit ... the greater the amount of fixed cost in the operating cost structure, other things being equal, the greater will be the impact on (operating) profits from a given change in sales ". ${ }^{3}$

(B ) Operating leverage refers "to the extent to which fixed cost are used in a firm's operations". ${ }^{4}$

Definition ( A ) which considers both the effect [ magnification of 'Operating Business Load' ( OBL ) i.e. absolute value ${ }^{5}$ of a percentage change ${ }^{6}$ in the initial value (assumed to be not equal to zero ) of Operating Earnings (OE) $\{$ dependent financial variable (DFV) $\}$ by the application of 'Operating Business Effort'( OBE ) i.e. absolute value of a percentage change in the initial value ( assumed to be not equal to zero ) of sales ( quantity or revenue ${ }^{7}$ ) \{ independent financial variable ( I FV ) \}, ceteris paribus in the functional relationship between the DFV and the IFV] and the cause [ presence of fixed operating cost within a firm's operating cost structure ] of operating leverage is more akin to the concept of 'physical leverage' ( the genesis of the concept of operating leverage ) and hence is more comprehensive and logical than definition (B) which considers only the cause.

The 'Net Operating Assets (NOA)' structure [ consisting of 'Operating Fixed Assets' (OFA) and 'Net Operating Current Assets' (NOCA) \{ or ' Net Operating Working Capital (NOWC $\left.)^{8}\right\}$ ] which gives rise to the operating cost structure \{ consisting of 'Variable Operating Cost' (VOC) and 'Fixed Operating Cost' (FOC) \} could be considered. However, the segregation of NOA into 'Variable Operating Cost - Bearing Net Operating Assets' ( VOCBNOA ) and 'Fixed Operating Cost Bearing Net Operating Assets' (FOCBNOA) renders some complexity as NOCA give rise to both $\operatorname{VOC}$ ( cash and non-cash) and FOC \{ in the form of 'Cash Fixed Operating Cost' (CFOC) \} whereas OFA give rise only to FOC $\{$ in the form of 'Non - Cash Fixed Operating Cost' ( NCFOC ) \{ i.e. depreciation and amortization of OFA \}. As a result, the explicit application of the NOA structure is subtly avoided from operating leverage analysis. Nevertheless, NOA may be brought into the analysis by considering 'Net Operating Assets Turnover Ratio' ( NOATR) $\{=$ ( Sales revenue ( S ) / Average NOA ) $\}$ and 'Return On Net Operating Assets' (RONOA) $\{=(\mathrm{OE} /$ Average NOA ) \} [ Average NOA being assumed to remain constant in both the formulae ] as another pair of IFV and DFV respectively.

A pertinent question whether the portion of income - tax ( payable by the firm) attributable to $\mathrm{OE}$ should be considered in the analysis of operating leverage, may arise. Income - tax is a peculiar item. With the realization of any item of revenue, it yields a 'notional cost' ( = revenue

\footnotetext{
1 This point will be illustrated further on the basis of an analogy between operating leverage and physical leverage.

${ }^{2}$ Fixed operating costs arise only in the short run.

${ }^{3}$ Gitman et all ( 1985 ) pg. 116 .

${ }^{4}$ Brigham \& Houston (2001) pg. 606.

${ }^{5}$ A change may be positive ( for increase) or negative ( for decrease). Hence, the absolute value ( modulus) of the change should be considered.
}

${ }^{6}$ A percentage change (a relative change) warrants more importance than an absolute change in financial analysis .

${ }^{7}$ Sales quantity $(q)$ or Sales revenue $(S)$ may be considered as the IFV in the case of a single productmanufacturing firm whereas only $S$ could be considered as the IFV in the case of a multiple productsmanufacturing firm.

${ }^{8}$ NOWC refers to the net working capital acquired with investor-supplied funds and is the excess of the Operating Current Assets (OCA ) ( such as cash or bank balance, account receivables, inventories, etc. required to maintain the firm's normal operating capability\} over Operating Current Liabilities (OCL) \{ such as account payables and accruals that arise spontaneously out of the firm's normal business operations and bear no explicit interest charges $\}$. It is assumed that NOWC $>0$. 
* effective income - tax rate ) \{ variable or fixed depending on the nature of the revenue \} for each item of revenue, and with the incurrence of any item of cost, it acts as a cost saver and yields a 'notional revenue' ( $=$ cost $*$ effective income - tax rate $)$ \{ variable or fixed depending on the nature of the cost $\}$ for each item of cost. Thus 'income-tax' is all pervasive in nature affecting all items of revenue and cost (and hence earnings or return). Hence, in operating leverage analysis (where the 'relative effect' of a percentage change in the initial value of the IFV on the percentage change in the initial value of the DFV is sought to be analysed ) it does not matter whether OE (or RONOA) is considered before-tax or after-tax. Moreover, the treatment of tax in case of negative OE ( i.e. operating loss) calls for unwarranted complexities and assumptions. So we will consider OE ( or RONOA) on a before - tax basis in the present analysis .

The following pairs of DFV and IFV will be considered in the present analysis .

TABLE 1

\begin{tabular}{|c|c|}
\hline Dependent Financial Variable ( DFV ) & Independent Financial Variable ( I FV ) \\
\hline Operating Earning ( before tax ) [ OE ] & Sales quantity ( q ) \\
\hline Operating Earning ( before tax ) [ OE ] & Sales revenue ( S ) \\
\hline $\begin{array}{c}\text { Return On Net Operating Assets } \\
\text { (before tax ) [ RONOA ] }\end{array}$ & $\begin{array}{c}\text { Net Operating Assets Turnover Ratio } \\
\text { ( NOATR ) }\end{array}$ \\
\hline
\end{tabular}

Assuming the existence of perfect competition in the product and input markets with selling price per unit ( $\mathrm{s}$ ) and variable operating cost per unit ( $\mathrm{v})$ being independent of quantity of sales ( q ), we get linear 'Sales revenue' ( $\mathrm{S}$ ), 'Total operating cost' ( $\mathrm{T}$ ), 'Operating Earnings' ( $\mathrm{OE}$ ) and 'Return On Net Operating Assets' (RONOA) functions for a short - run period as :

$\mathrm{S}=\mathrm{s} \mathrm{q}$

$\mathrm{T}=\mathrm{V}+\mathrm{F}=\mathrm{vq}+\mathrm{F}$

$\mathrm{OE}=\mathrm{S}-\mathrm{T}=(\mathrm{S}-\mathrm{V})-\mathrm{F}=\mathrm{C}-\mathrm{F}=\mathrm{c} \mathrm{q}-\mathrm{F}=\mathrm{rS}-\mathrm{F}$

RONOA $=($ OE $/$ ANOA $)=\mathrm{r} *$ NOATR $-(\mathrm{F} /$ ANOA $)$

where $\mathrm{c}=$ contribution margin per unit of sales $=(\mathrm{s}-\mathrm{v})$;

$\mathrm{V}($ Variable operating cost $)=\mathrm{vq}$;

$\mathrm{F}=$ Fixed operating cost ;

$\mathrm{C}($ contribution margin $)=(\mathrm{S}-\mathrm{V})=\mathrm{c} \mathrm{q}$;

$\mathrm{r}\{($ profit $/$ volume $)$ ratio $\}=\{(\mathrm{s}-\mathrm{v}) / \mathrm{s}\}=(\mathrm{c} / \mathrm{s})=\{1-(\mathrm{v} / \mathrm{s})$;

ANOA $=$ Average NOA $=\{($ Opening NOA + Closing NOA $) / 2\} ;$

NOATR ( Net Operating Assets Turnover Ratio $)=(\mathrm{S} /$ ANOA $)$;

$\mathrm{q} \geq 0, \mathrm{~s}>0,0 \leq \mathrm{v}<\mathrm{s}$ [ i. e. $0<\mathrm{c} \leq \mathrm{s}$, so that the question of shutting down of operations does not arise ] and $0<\mathrm{r}<1$.

The linear functional relationship between OE ( or RONOA) and q or S (or NOATR) being direct, operating leverage is said to be :

(a) favourable, when there is a magnified percentage increase in the initial value of $\mathrm{OE}$ ( or RONOA) for one percentage increase in the initial value of $\mathrm{q}$ or S ( or NOATR); and

( b ) unfavourable, when there is a magnified percentage decrease in the initial value of $\mathrm{OE}$ ( or RONOA) for one percentage decrease in the initial value of q or $\mathrm{S}$ ( or NOATR) ;

thus rendering it to be a double - edged sword .

The 'Operating Break - Even Point' ( OBEP) [ i .e. the value of $\mathrm{q}$ or S ( or NOATR) for which $\mathrm{OE}$ ( or RONOA) is zero ] is given from eqs. ( 8 ) \& (9) as :

$\operatorname{OBEP}(\mathrm{q})=(\mathrm{F} / \mathrm{c})$

$\operatorname{OBEP}(\mathrm{S})=(\mathrm{F} / \mathrm{r})$

(11)

$\operatorname{OBEP}(\operatorname{NOATR})=\{\mathrm{F} /(\mathrm{r} *$ ANOA $)\}$

(12)

Since a percentage change ( a relative change) can be measured only when the initial value is not equal to zero, the definition of operating leverage presupposes that the firm will not actually attain the break - even sales $[\mathrm{OE} \neq 0\{$ or RONOA $\neq 0\}$ ] and OBEP will only be used as a point of reference .

Generalizing the linear and direct functional relationship between the DFV and the IFV $\{$ vide eq. ( 8$)$ or $(9)\}$ as :

$\mathrm{y}=\mathrm{dx}-\mathrm{f} 9$

\footnotetext{
${ }^{9}$ For :-

(a) $x=q$ and $y=O E: d=c=(s-v)$ and $f=F$;

(b) $x=S$ and $y=O E: d=r=(c / s)=\{(s-v) / s\}$ and $f=F$;

(c) $x=$ NOATR and $y=$ RONOA : $d=r$ and $f=(F / A N O A)$.
} 
where $\mathrm{y}(-\infty<\mathrm{y}<\infty)$ and $\mathrm{x}(>0)$ are the DFV and the IFV respectively;

' $d$ ' $(>0)$ is the rate of change (finite or infinitesimally small) of $y$ with respect to $x$;

' $\mathrm{f}$ ' $(\geq 0)$ is the fixed operating cost per unit of the related item in the net operating assets structure or operating cost structure or the 'fixed operating cost component'.

If the initial and the final values of $\mathrm{x}$ and $\mathrm{y}$ be $\mathrm{x}_{\mathrm{i}}(\neq 0)$ and $\mathrm{y}_{\mathrm{i}}(\neq 0)$, and $\mathrm{x}_{\mathrm{f}}$ and $\mathrm{y}_{\mathrm{f}}$ respectively, then from eq. ( 13 ), ceteris paribus $\{$ ' $d$ ' and ' $f$ ' held constant $\}$, we get :

$\mathrm{y}_{\mathrm{i}}=\mathrm{d} * \mathrm{x}_{\mathrm{i}}-\mathrm{f}$

$\mathrm{y}_{\mathrm{f}}=\mathrm{d} * \mathrm{x}_{\mathrm{f}}-\mathrm{f}$

Now, the absolute values (moduli) of the finite changes and percentage changes in $\mathrm{x}$ and $\mathrm{y}$, ceteris paribus, are given as:

$|\Delta \mathrm{x}|=\left|\mathrm{x}_{\mathrm{f}}-\mathrm{x}_{\mathrm{i}}\right|$

$|\Delta \mathrm{y}|=\left|\mathrm{y}_{\mathrm{f}}-\mathrm{y}_{\mathrm{i}}\right|=|\mathrm{d} * \Delta \mathrm{x}|$

$|\% \Delta \mathrm{x}|=\left|\left(\Delta \mathrm{x} / \mathrm{x}_{\mathrm{i}}\right) * 100 \%\right|=\left\{|\Delta \mathrm{x}| /\left|\mathrm{x}_{\mathrm{i}}\right|\right\} * 100 \%$

$|\% \Delta \mathrm{y}|=\left|\left(\Delta \mathrm{y} / \mathrm{y}_{\mathrm{i}}\right) * 100 \%\right|=\left\{|\Delta \mathrm{y}| /\left|\mathrm{y}_{\mathrm{i}}\right|\right\} * 100 \%$

A measure of the degree of magnification of $(\% \Delta y)$ for $(1 \% \Delta y)$ is given by :

$\mathrm{L}=\{|\% \Delta \mathrm{y}| /|\% \Delta \mathrm{x}|\}=\left[\left|\mathrm{d}^{*} \mathrm{x}_{\mathrm{i}}\right| /\left|\mathrm{y}_{\mathrm{i}}\right|\right]$, or

$\mathrm{L}=\left[\mathrm{d} *\left|\mathrm{x}_{\mathrm{i}}\right| /\left\{\left|\mathrm{d} * \mathrm{x}_{\mathrm{i}}-\mathrm{f}\right|\right\}\right] \quad[$ since $\mathrm{d}>0]$

The question of the existence of the operating leverage effect ( i.e. L > 1) arises only if $\mathrm{f}>0$. Hence, the presence of fixed operating cost in the operating cost structure is the actual cause of the operating leverage effect.

The "ceteris paribus" condition in the functional relationship between the DFV and the I FV is a sine qua non for measuring the operating leverage effect (i.e. the relative degree of magnification ) and an 'Operating Account Structural ${ }^{10}$ Plan' (OASP) [ which may be defined as a strategic combination 'Net Operating Assets (NOA) structure' \{ consisting of operating fixed assets and net operating current assets \}, 'operating revenue structure' \{consisting of operating revenue (or sales) per unit ( s ) \} and 'operating cost structure' \{consisting of variable operating cost per unit (v) and fixed operating cost (F) \}] the values of whose components ( NOA , s , v and $\mathrm{F}$ ) satisfy the 'ceteris paribus' condition in the functional relationship between the DFV and the IFV , may be construed to act as a 'Notional Operating Business Fulcrum'( NOBF) ; the 'Actual Operating Business Fulcrum' ( AOBF) being the determinable fixed cost - bearing component of the OASP ( i.e. fixed operating cost ).

An analogy (to be extended as we proceed ) between 'physical leverage' and 'operating leverage' may now be enumerated as follows :

(a) Physical Effort ( PE ) [ magnitude of effort force \{ independent physical variable ( IPV) \} or absolute change in the initial magnitude $(=0)$ of the effort force $]\{$ i.e. $(\Delta \mathrm{IPV})\} \approx$ Operating Business Effort (OBE ) i.e. absolute value of a percentage change in the initial value $(\neq 0)$ of an independent financial variable ( IFV) [ i.e. $|\% \Delta \mathrm{IFV}|$ ];

(b) Physical Load ( PL ) [ magnitude of load force $\{$ dependent physical variable (DPV) $\}$ or absolute change in the initial magnitude $(=0)$ of the load force ] \{ i.e. $(\Delta$ DPV $)\} \approx$ Operating Business Load ( OBL ) i.e. absolute value of a percentage change in the initial value $(\neq 0)$ of a dependent financial variable $(\mathrm{DFV})\}$ [ i.e. $|\% \Delta \mathrm{DFV}|$ ] ;

(c) the effect of physical leverage is the magnification of 'Physical Load' by the application of 'physical effort' $\approx$ the effect of operating leverage is the magnification of 'Operating Business Load' ( OBL ) by the application of 'Operating Business Effort' (OBE ) ;

(d) Physical Fulcrum ( PF ) whose position remains fixed during a particular action of the physical lever [ i.e. IMA \{ vide eq. (1) \} representing the position of the $\mathbf{P F}$ remains constant in the functional relationship \{ vide eq. (3) \} between the load force (DPV) and the effort force ( IPV)] and which causes the 'physical leverage effect'

$\approx$ (i ) 'Notional Operating Business Fulcrum' ( NOBF ) i.e. an 'Operating Account Structural Plan' ( OASP), the values of whose components ( NOA, s, v and F) are assumed to remain constant in the functional relationship between the DFV and the IFV; or

${ }^{10}$ The basic account structures [ an 'account structure' may be defined as a well defined group of elements, having some similar characteristics, which serves as a fundamental component of the accounting statements comprising the managerial accounting decision system of a firm I include asset structure, capital structure , revenue structure and cost structure. 
Operating Leverage Analysis - A Conceptual Framework

(ii ) 'Actual Operating Business Fulcrum' (AOBF) i.e. Fixed operating cost (F), whose presence in the operating cost structure ( and hence in an OASP) is the cause of the operating leverage effect ;

(e) Physical Lever i.e. a simple machine which has the ability to create the physical leverage effect in the presence of physical fulcrum based on the principle of linear moments $\approx$ Operating Lever i.e. a business firm which has the ability to create the operating leverage effect in the presence of an OASP (and hence fixed operating cost) based on the linear functional relationship between the DFV and the IFV ].

We may now re-define 'operating leverage' as the ability of a business firm to magnify 'Operating Business Load' (OBL) i.e. absolute value of a percentage change in the initial value ( assumed to be not equal to zero ) of 'Operating Earnings' (OE ) \{ or 'Return On Net Operating Assets' ( RONOA ) \} [ dependent financial variable (DFV)] by the application of 'Operating Business Effort' ( OBE ) i.e. absolute value of a percentage change in the initial value ( assumed to be not equal to zero ) of sales ( quantity or revenue) \{ or 'Net Operating Assets Turnover Ratio' (NOATR) \} [ independent financial variable ( IFV) \} ] by considering an 'Operating Account Structural Plan' ( OASP ) [ i.e. a strategic combination ' Net Operating Assets (NOA) structure' $\{$ consisting of operating fixed assets and net operating current assets \}, 'operating revenue structure' $\{$ consisting of 'operating revenues per unit' or 'selling price per unit' (s) \} and 'operating cost structure' $\{$ consisting of 'variable operating cost per unit' ( v ) and 'Fixed operating cost' (F) \} ], the values of whose components ( $\mathrm{NOA}, \mathrm{s}, \mathrm{v}$ and $\mathrm{F}$ ) are assumed to remain constant in the functional relationship between the DFV and the IFV, with 'OASP' and ' $F$ ' acting as the 'Notional Operating Business Fulcrum' ( NOBF) and the 'Actual Operating Business Fulcrum' ( AOBF ) respectively. The following diagram illustrates the concept of operating leverage :

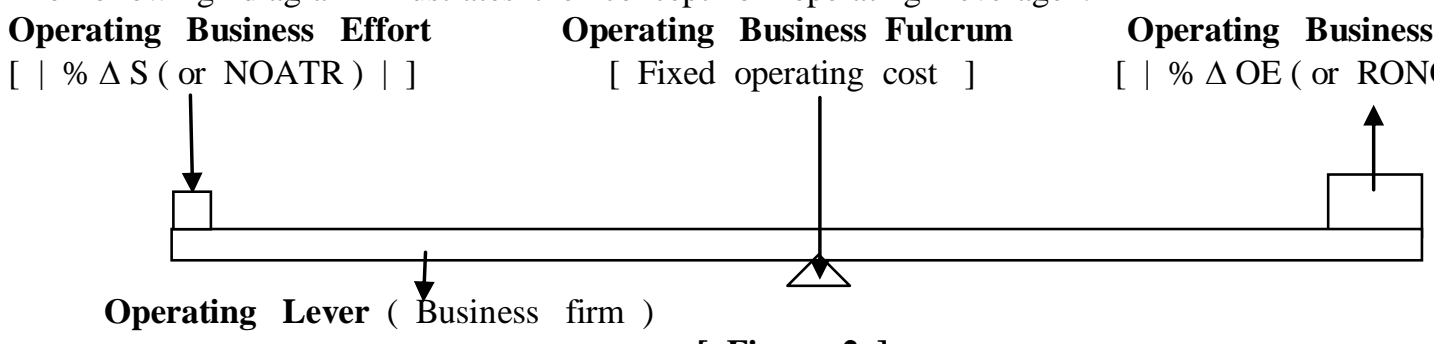

[ Figure 2 ]

\subsection{MEASURES OF ' DEGREE OF OPERATING LEVERAGE，( DOL )}

Extending the analogy between physical leverage and operating leverage (page 5 ) we get the measures of the 'Degree of Operating Leverage' (DOL) as follows:

(f) Degree of Physical Leverage ( DPL ) is given by :

(i) \{ Physical Load / Physical Effort \} i .e. I M A \{ vide eq. (4) \} or AMA \{vide eq. (2) \} [ a measure of the degree of the 'physical leverage effect' ] ; or

(ii) ( effort arm / load arm ) i .e. I M A vide eq.(1) \{ or the relative position of the physical fulcrum with respect to the effort and the load forces \} [ a measure of the degree of the 'cause of the physical leverage effect']

$\approx$ Degree of Operating Leverage ( DOL) is given by:

(i) ( Operating Business Load / Operating Business Effort)

i.e. $\{|\% \Delta \mathrm{DFV}| /|\% \Delta \mathrm{IFV}|\}$, which is a measure of the degree of the 'operating leverage effect' and which may be connoted as the 'elasticity coefficient measure' of DOL ( represented by $\left.\mathrm{DOL}_{\mathrm{E}}\right) ;$ or

(ii) relative proportion of 'Fixed operating cost' ( F) within the total operating cost structure \{ i.e. $(\mathrm{F} / \mathrm{V}){ }^{11}$ or $\left.(\mathrm{F} / \mathrm{T})\right\}$ [ relative proportion of ' $\mathrm{NOA}$ ' in 'NOA structure' or the relative proportion of ' $\mathrm{s}$ ' in 'operating revenue structure' being equal to one ], which is a measure of the degree of the cause of the operating leverage effect and which may be connoted as the 'operating cost structural measure' of DOL ( represented by $\mathrm{DOL}_{\mathrm{S}}$ );

(g) I M A vide eq.(1) [ or the relative position of the physical fulcrum with respect to the effort and the load forces] directly affects IM A [ vide eq. (4)] or AMA [vide eq. (2)] $\approx$ DOL $_{S}$ may be said to directly affect $\mathrm{DOL}_{\mathrm{E}}$, ceteris paribus .

The measures of DOL are discussed below.

${ }^{11}(F / v)$ based on the operating cost structure (and not the total operating cost structure) cannot be construed to be a mathematically valid measure of $D O L_{S}$ as it is not a dimensionless number. 
Operating Leverage Analysis - A Conceptual Framework

( A ) ELASTICITY COEFFICIENT MEASURE

It is a measure of the effect operating leverage, given as :

| Percentage change in the initial value $(\neq 0)$ of DFV

$\{$ OE $($ or RONOA $)\}$

DOLE $=$

| Percentage change in the initial value $(\neq 0)$ of IFV

$\{\mathrm{q}$ or $\mathrm{S}($ or NOATR $)\}$ |

CASE 1: IFV $=q$, DFV $=$ OE

Considering that, for $\mathrm{x}=\mathrm{q}: \mathrm{d}=\mathrm{c}=(\mathrm{s}-\mathrm{v})$ and $\mathrm{f}=\mathrm{F}$, we get from eqs. ( 8), (20) \& (21) :

$\mathrm{DOL}_{\mathrm{E}}=\left\{(\mathrm{s}-\mathrm{v}) * \mathrm{q}_{\mathrm{i}}\right\} /\left\{\left|(\mathrm{s}-\mathrm{v}) * \mathrm{q}_{\mathrm{i}}-\mathrm{F}\right|\right\}$, or

$\mathrm{DOL}_{\mathrm{E}}=\left[\left(\mathrm{c} * \mathrm{q}_{\mathrm{i}}\right) /\left\{\left|\mathrm{c} * \mathrm{q}_{\mathrm{i}}-\mathrm{F}\right|\right\}\right]=\left[\mathrm{C}_{\mathrm{i}} /\left|\mathrm{OE}_{\mathrm{i}}\right|\right]$

\section{A special note :}

From eq. (22) we observe that $D O L_{E}$ varies directly with ' $v$ ' or ' $F$ ', ceteris paribus in the functional relationship between $D O L_{E}$ and $q_{i}$. However, if theoretically $v=0$ ( with $s, q_{i}$ and $F>0$ ) then $D O L_{E}=\{S /(S-F)\}>1$, whereas if $F=0\left(\right.$ with $s, v$ and $\left.q_{i}>0\right)$ then $D O L_{E}=1$. The presence of ' $v$ ' in the operating cost structure can never be construed to be $a$ cause of the operating leverage effect ; ' $v$ ' (like ' $s$ ') only satisfies the 'ceteris paribus' condition in the functional relationship between $O E$ and $q_{i}$, enabling the measurement of $D O L_{E}$; whereas ' $F$ ' while satisfying the 'ceteris paribus' condition acts as the only cause of the operating leverage effect.]

$\operatorname{DOL}_{\mathrm{E}}(>0)$ is thus a non-linear function of $\mathrm{q}_{\mathrm{i}}$ defined for $\left(\mathrm{c}^{*} \mathrm{q}_{\mathrm{i}}-\mathrm{F}\right) \neq 0 \Rightarrow \mathrm{q}_{\mathrm{i}} \neq(\mathrm{F} / \mathrm{c})$ $\left[(\mathrm{F} / \mathrm{c})=\operatorname{OBEP}_{(\mathrm{q})}\right]$

So letting $\operatorname{OBEP}_{(\mathrm{q})}=\mathrm{b}$, we get from eq. (22):

$\operatorname{DOL}_{\mathrm{E}}=\left[\mathrm{q}_{\mathrm{i}} /\left\{\left|\mathrm{q}_{\mathrm{i}}-\mathrm{b}_{(\mathrm{q})}\right|\right\}\right]$

From eq. (23) we get :

$\operatorname{DOL}_{\mathrm{E}}=1 /\left[\left\{\left|\mathrm{q}_{\mathrm{i}}-\mathrm{b}_{(\mathrm{q})}\right|\right\} / \mathrm{q}_{\mathrm{i}}\right]=\left\{1 /\left|\mathrm{OMS}_{(\mathrm{q})}\right|\right\}$

where $\operatorname{OMS}_{(\mathrm{q})}\{$ Operating Margin of Safety $\}$ is the excess of $q_{i}$ over $\operatorname{OBEP}_{(q)}$ expressed as a proportion of $\mathrm{q}_{\mathrm{i}}$.

Since $\mathrm{c}>0$ and $\mathrm{F} \geq 0$, we get from eq.(22):

$\mathrm{DOL}_{\mathrm{E}}=\left\{1+\left(\mathrm{F} /\left|\mathrm{OE}_{\mathrm{i}}\right|\right)\right\}$

Hence, $\mathrm{DOL}_{\mathrm{E}}$ is a non-linear function of $\mathrm{OE}_{\mathrm{i}}$ defined for $\mathrm{OE}_{\mathrm{i}} \neq 0$.

CASE 2 : I FV $=S$, DFV $=$ OE

Results of CASE 1 will be obtained by replacing :

(i) $\mathrm{q}$ with $\mathrm{S}$, (ii) $\mathrm{v}$ with $\left(1-\mathrm{r}\right.$ ), (iii) $\mathrm{c}$ with $\mathrm{r}$, (iv) $\mathrm{b}_{(\mathrm{q})}$ with $\mathrm{b}_{(\mathrm{S})}$ and

( v ) $\mathrm{OMSS}_{(\mathrm{q})}$ with $\mathrm{OMS}_{(\mathrm{s})}$.

CASE $3:$ I FV = NOATR, DFV = RONOA

Results of CASE 1 will be obtained by replacing :

( i ) $\mathrm{q}$ with NOATR, (ii) OE with RONOA, (iii) $\mathrm{v}$ with $(1-\mathrm{r})$, (iv) $\mathrm{c}$ with $(\mathrm{r} *$ ANOA ),

(v) $b_{(q)}$ with $b_{(\text {NOATR })}$, and (vi ) OMS $(q)$ with OMS (NOATR).

(B) OPERATING COST STRUCTURAL MEASURE

This is a measure of the cause of the operating leverage effect, representing the "relative proportion of fixed operating cost within the total operating cost structure' given by :

DOL $_{\mathrm{S}}=\frac{\text { Amount of Fixed operating } \operatorname{cost}(\mathrm{F})}{\text { Amount of Variable operating }}{ }^{12}$, ost $(\mathrm{V})$
DOL $_{\mathrm{S}}=(\mathrm{F} / \mathrm{vq})=[\mathrm{F} /\{(1-\mathrm{r}) * \mathrm{~S}\}]=\mathrm{F} /[\{(1-\mathrm{r}) \mathrm{NOA}\} *$ NOATR $]$

CASE $1:$ IFV $=q$, DFV $=$ OE

From eq. (26) we observe that $\mathrm{DOL}_{s}$ is a non-linear function of $\mathrm{q}$ defined for $\mathrm{q} \neq 0$ or $\mathrm{v} \neq 0$ and $\mathrm{DOL}_{\mathrm{S}} \geq 0$.

From eq. ( 26 ) we get :

$\mathrm{F}=\left(\mathrm{v} * \mathrm{q} * \mathrm{DOL}_{\mathrm{s}}\right)$

So from eqs. (22) and (27) we get $\mathrm{DOL}_{\mathrm{E}}$ at a given value of $\mathrm{q}_{\mathrm{i}}(\neq 0)$ as :

12 Another variant of $\mathrm{DOL}_{S}$ is the ratio of fixed operating cost to total operating cost i.e. $\{(F /(F+V)\}$. 
$\operatorname{DOL}_{\mathrm{E}}=\left[\left(\mathrm{c} * \mathrm{q}_{\mathrm{i}}\right) /\left\{\left|\left(\mathrm{c} * \mathrm{q}_{\mathrm{i}}\right)-\mathrm{v} * \mathrm{q}_{\mathrm{i}} * \mathrm{DOL}_{\mathrm{S}}\right|\right\}\right]$, or $\left(\right.$ since $\left.\mathrm{q}_{\mathrm{i}} \neq 0\right)$

$\mathrm{DOL}_{\mathrm{E}}=\left[\mathrm{c} /\left\{\left|\mathrm{c}-\mathrm{v} * \mathrm{DOL}_{\mathrm{S}}\right|\right\}\right]$

Thus $\mathrm{DOL}_{\mathrm{E}}$ is a non-linear direct function of $\mathrm{DOL}_{\mathrm{S}}$ defined for $\mathrm{DOL}_{\mathrm{S}} \neq(\mathrm{c} / \mathrm{v})$.

Hence $\mathrm{DOL}_{\mathrm{S}}$ directly affects $\mathrm{DOL}_{\mathrm{E}}$.

CASE 2: I FV $=S$, DFV $=$ OE

Results of CASE 1 will be obtained by replacing :

(i) $\mathrm{q}$ with $\mathrm{S}$, (ii) $\mathrm{v}$ with $(1-\mathrm{r}$ ), and (iii) $\mathrm{c}$ with $\mathrm{r}$.

CASE $3:$ I FV = NOATR, DFV = RONOA

Results of CASE 1 will be obtained by replacing :

(i) $\mathrm{q}$ with NOATR, (ii) $\mathrm{v}$ with $(1-\mathrm{r})$, and (iii) $\mathrm{c}$ with $(\mathrm{r} *$ ANOA) .

\subsection{CONDITIONS FOR EXISTENCE AND NON-EXISTENCE OF OPERATING LEVERAGE EFFECT}

CASE 1: IFV $=q$, DFV $=$ OE

Let us now deduce [ from eq.(23)] the conditions for the existence and non-existence of the operating leverage effect, considering that $F \geq 0$ and $c>0\left[\right.$ hence $\left.b_{(q)} \geq 0\right], q_{i} \neq b_{(q)}$ and $\mathrm{DOL}_{\mathrm{E}}>0$.

The operating leverage effect will exist when $\mathrm{DOL}_{\mathrm{E}}>1$ i.e. when :

(a) $\mathrm{q}_{\mathrm{i}}>0, \mathrm{~b}_{(\mathrm{q})}>0$ and $\left\{\mathrm{q}_{\mathrm{i}}-\mathrm{b}_{(\mathrm{q})}\right\}>0\left[\Rightarrow \mathrm{q}_{\mathrm{i}}>\mathrm{b}_{(\mathrm{q})}\right]$, or

(b) $\mathrm{q}_{\mathrm{i}}>0, \mathrm{~b}_{(\mathrm{q})}>0$ and $\mathrm{q}_{0}>-\left\{\mathrm{q}_{\mathrm{i}}-\mathrm{b}_{(\mathrm{q})}\right\}$

$\left[\Rightarrow 2 \mathrm{q}_{\mathrm{i}}>\mathrm{b}_{(\mathrm{q})} \Rightarrow \mathrm{q}_{\mathrm{i}}>\left\{\mathrm{b}_{(\mathrm{q})} / 2\right)\right]$.

Hence the operating leverage effect will exist in the presence of fixed operating cost in the operating cost structure, when $\left\{\mathbf{b}_{(\mathbf{q})} / 2\right\}<\mathbf{q}_{\mathrm{i}}<\mathbf{b}_{(\mathbf{q})}$ or $\mathbf{q}_{\mathbf{i}}>\mathbf{b}_{(\mathbf{q})}$.

The operating leverage effect will not exist when:

(1) $\mathrm{DOL}_{\mathrm{E}}=1$ i.e. when :

(a) $\mathrm{q}_{\mathrm{i}}>0$ and $\mathrm{b}_{(\mathrm{q})}=0[\Rightarrow \mathrm{F}=0$ since $\mathrm{c}>0]$;

(b) $\mathrm{q}_{\mathrm{i}}>0, \mathrm{~b}_{(\mathrm{q})}>0$ and $\mathrm{q}_{\mathrm{i}}=-\left\{\mathrm{q}_{\mathrm{i}}-\mathrm{b}_{(\mathrm{q})}\right\}\left[\Rightarrow 2 \mathrm{q}_{\mathrm{i}}=\mathrm{b}_{(\mathrm{q})} \Rightarrow \mathrm{q}_{\mathrm{i}}=\left\{\mathrm{b}_{(\mathrm{q})} / 2\right\}\right]$.

( 2) $0<\mathrm{DOL}_{\mathrm{E}}<1$ i.e. when $\mathrm{q}_{\mathrm{i}}>0, \mathrm{~b}_{(\mathrm{q})}>0$ and

$\mathrm{q}_{\mathrm{i}}<-\left(\mathrm{q}_{\mathrm{i}}-\mathrm{b}_{(\mathrm{q})}\right)\left[\Rightarrow 2 \mathrm{q}_{\mathrm{i}}<\mathrm{b}_{(\mathrm{q})} \Rightarrow \mathrm{q}_{\mathrm{i}}<\left\{\mathrm{b}_{(\mathrm{q})} / 2\right\}\right]$.

Hence the operating leverage effect will not exist :

(a) in the absence of fixed operating cost ;

(b) in the presence of fixed operating cost when $0<q_{i} \leq\left\{b_{(q)} / 2\right\}$.

The conditions for the existence of the operating leverage effect at a given value of $\mathrm{q}_{\mathrm{i}}$ $\left[\left\{\mathrm{b}_{(\mathrm{q})} / 2\right\}<\mathrm{q}_{\mathrm{i}}<\mathrm{b}_{(\mathrm{q})}\right.$ or $\left.\mathrm{q}_{\mathrm{i}}>\mathrm{b}_{(\mathrm{q})}\right]$, in terms of $\operatorname{DOL}_{\mathrm{S}}$, considering $\mathrm{b}_{(\mathrm{q})}=(\mathrm{F} / \mathrm{c})$ and eq. (27), may be derived as follows :

$\left\{\mathrm{b}_{(\mathrm{q})} / 2\right\}<\mathrm{q}_{\mathrm{i}}<\mathrm{b}_{(\mathrm{q})}$ or $\mathrm{q}_{\mathrm{i}}>\mathrm{b}_{(\mathrm{q})}$

$\Rightarrow(\mathrm{F} / 2 \mathrm{c})<\mathrm{q}_{\mathrm{i}}<(\mathrm{F} / \mathrm{c})$ or $\mathrm{q}_{\mathrm{i}}>(\mathrm{F} / \mathrm{c})$

$\Rightarrow\left\{\left(\mathrm{v} * \mathrm{q}_{\mathrm{i}} * \mathrm{DOL}_{\mathrm{S}}\right) / 2 \mathrm{c}\right\}<\mathrm{q}_{\mathrm{i}}<\left\{\left(\mathrm{v} * \mathrm{q}_{\mathrm{i}} * \mathrm{DOL}_{\mathrm{S}}\right) / \mathrm{c}\right\}$

or $\mathrm{q}_{\mathrm{i}}>\left\{\left(\mathrm{v} * \mathrm{q}_{\mathrm{i}} * \mathrm{DOL}_{\mathrm{S}}\right) / \mathrm{c}\right\}$

$\Rightarrow\left(\mathrm{C}_{\mathrm{i}} / \mathrm{V}_{\mathrm{i}}\right)<\mathrm{DOL}_{\mathrm{S}}<\left(2 \mathrm{C}_{\mathrm{i}} / \mathrm{V}_{\mathrm{i}}\right)$ or $0<\mathrm{DOL}_{\mathrm{S}}<\left(\mathrm{C}_{\mathrm{i}} / \mathrm{V}_{\mathrm{i}}\right)$

$\Rightarrow(\mathrm{c} / \mathrm{v})<\mathrm{DOL}_{\mathrm{S}}<(2 \mathrm{c} / \mathrm{v})$ or $0<\mathrm{DOL}_{\mathrm{S}}<(\mathrm{c} / \mathrm{v}) \quad\left[\right.$ since $\left.\mathrm{q}_{\mathrm{i}} \neq 0\right]$.

Hence the operating leverage effect will :

(a) exist, when $(\mathrm{c} / \mathrm{v})<\mathrm{DOL}_{\mathrm{S}}<(2 \mathrm{c} / \mathrm{v})$ or $0<\mathrm{DOL}_{\mathrm{S}}<(\mathrm{c} / \mathrm{v})$;

(b) not exist, when DOL $_{S}=0$ or DOL $_{S} \geq(2 \mathrm{c} / \mathrm{v})$.

CASE 2 : IFV $=$ S , DFV $=$ OE \& CASE $3:$ I FV $=$ NOATR, DFV $=$ RONOA

Results of CASE 1 will be obtained.

\section{Operating Leverage And Risk}

The literal meaning of the term 'risk' is the (exposure to ) the possibility of loss, injury, or other adverse or unwelcome circumstance; a chance or situation involving such a possibility ${ }^{13}$. However , in finance the term 'risk' encompasses both favourable and unfavourable outcomes of the expected variability of an investment's actual return from the expected return. Frank Knight ( 1921 ) interprets 'risk' as situations where mathematical probabilities could be assigned by the decision - maker to the randomness faced by him.

${ }^{13}$ Oxford English Dictionary 
Considering an 'Operating Account Structural Plan' (OASP) whose elements NOA, s , v and $\mathrm{F}$ are assumed to be independent of $\mathrm{q}$; with $\mathrm{q}$, NOA, $\mathrm{s}, \mathrm{v}$ and $\mathrm{F}$ being random variables (NOA, $s, v$ and $F$ being constant random variables) whose statistical expected values expected to be observed at the end of a short-run period ( time ' 0 ' to time ' $t$ ') are given as:

$\mathrm{E}\left(\mathrm{q}_{\mathrm{t}}\right)=\Sigma\left\{\left(\mathrm{q}_{\mathrm{t}}\right)_{\mathrm{m}} * \mathrm{p}_{\mathrm{m}}\right\} ;$

$\mathrm{E}\left(\mathrm{NOA}_{\mathrm{t}}\right)=\Sigma\left\{\left(\mathrm{NOA}_{\mathrm{t}}\right)_{\mathrm{m}} * \mathrm{p}_{\mathrm{m}}\right\}=\left(\mathrm{NOA}_{\mathrm{t}}\right)_{\mathrm{m}} ;$

$\mathrm{E}\left(\mathrm{s}_{\mathrm{t}}\right)=\Sigma\left\{\left(\mathrm{s}_{\mathrm{t}}\right)_{\mathrm{m}} * \mathrm{p}_{\mathrm{m}}\right\}=\left(\mathrm{s}_{\mathrm{t}}\right)_{\mathrm{m}} ;$

$\mathrm{E}\left(\mathrm{v}_{\mathrm{t}}\right)=\Sigma\left\{\left(\mathrm{v}_{\mathrm{t}}\right)_{\mathrm{m}} * \mathrm{p}_{\mathrm{m}}\right\}=\left(\mathrm{v}_{\mathrm{t}}\right)_{\mathrm{m}} ;$

$\mathrm{E}\left(\mathrm{F}_{\mathrm{t}}\right)=\Sigma\left\{\left(\mathrm{F}_{\mathrm{t}}\right)_{\mathrm{m}} * \mathrm{p}_{\mathrm{m}}\right\}=\left(\mathrm{F}_{\mathrm{t}}\right)_{\mathrm{m}} ; \quad(\mathrm{m}=1,2,3 \ldots \mathrm{n}) ;$

$\left[\left(\mathrm{q}_{\mathrm{t}}\right)_{\mathrm{m}},\left(\mathrm{NOA}_{\mathrm{t}}\right)_{\mathrm{m}},\left(\mathrm{s}_{\mathrm{t}}\right)_{\mathrm{m}},\left(\mathrm{v}_{\mathrm{t}}\right)_{\mathrm{m}}\right.$ and $\left(\mathrm{F}_{\mathrm{t}}\right)_{\mathrm{m}}$ are the $\mathrm{m}^{\text {th }}$ possible periodic values under ' $n$ ' possible future business scenarios and $\mathrm{p}_{\mathrm{m}}$ is the probability ( subjectively assigned by the decision maker) of the occurrence of the $\mathrm{m}^{\text {th }}$ possible future business scenario ];

we get from eqs. (6), (7), (8) \& (9) the expected periodic values of the related variables as :

$\mathrm{E}\left(\mathrm{S}_{\mathrm{t}}\right)=\mathrm{E}\left(\mathrm{s}_{\mathrm{t}}\right) * \mathrm{E}\left(\mathrm{q}_{\mathrm{t}}\right)$

$\mathrm{E}\left(\mathrm{T}_{\mathrm{t}}\right)=\mathrm{E}\left(\mathrm{V}_{\mathrm{t}}\right)+\mathrm{E}\left(\mathrm{F}_{\mathrm{t}}\right)=\mathrm{E}\left(\mathrm{v}_{\mathrm{t}}\right) * \mathrm{E}\left(\mathrm{q}_{\mathrm{t}}\right)+\mathrm{E}\left(\mathrm{F}_{\mathrm{t}}\right)$

$\mathrm{E}\left(\mathrm{OE}_{\mathrm{t}}\right)=\mathrm{E}\left(\mathrm{C}_{\mathrm{t}}\right)-\mathrm{E}\left(\mathrm{F}_{\mathrm{t}}\right)=\mathrm{E}\left(\mathrm{c}_{\mathrm{t}}\right) * \mathrm{E}\left(\mathrm{q}_{\mathrm{t}}\right)-\mathrm{E}\left(\mathrm{F}_{\mathrm{t}}\right)=\mathrm{E}\left(\mathrm{r}_{\mathrm{t}}\right) * \mathrm{E}\left(\mathrm{S}_{\mathrm{t}}\right)-\mathrm{E}\left(\mathrm{F}_{\mathrm{t}}\right)$

(31)

$\mathrm{E}\left(\mathrm{RONOA}_{\mathrm{t}}\right)=\mathrm{E}\left(\mathrm{r}_{\mathrm{t}}\right) * \mathrm{E}\left(\operatorname{NOATR}_{\mathrm{t}}\right)-\left\{\mathrm{E}\left(\mathrm{F}_{\mathrm{t}}\right) / \mathrm{E}\left(\mathrm{ANOA}_{\mathrm{t}}\right)\right\}$

where $\mathrm{E}\left(\mathrm{c}_{\mathrm{t}}\right)=\left\{\mathrm{E}\left(\mathrm{s}_{\mathrm{t}}\right)-\mathrm{E}\left(\mathrm{v}_{\mathrm{t}}\right)\right\} ; \mathrm{E}\left(\mathrm{r}_{\mathrm{t}}\right)=\left\{\mathrm{E}\left(\mathrm{c}_{\mathrm{t}}\right) / \mathrm{E}\left(\mathrm{s}_{\mathrm{t}}\right)\right\} ;$

$\mathrm{E}\left(\mathrm{V}_{\mathrm{t}}\right)=\Sigma\left\{\left(\mathrm{V}_{\mathrm{t}}\right)_{\mathrm{m}} * \mathrm{p}_{\mathrm{m}}\right\}\left[\left(\mathrm{V}_{\mathrm{t}}\right)_{\mathrm{m}}=\left\{\mathrm{E}\left(\mathrm{v}_{\mathrm{t}}\right) *\left(\mathrm{q}_{\mathrm{t}}\right)_{\mathrm{m}}\right\}=\left\{\left(\mathrm{v}_{\mathrm{t}}\right)_{\mathrm{m}} *\left(\mathrm{q}_{\mathrm{t}}\right)_{\mathrm{m}}\right\}\right] ;$

$\mathrm{E}\left(\mathrm{S}_{\mathrm{t}}\right)=\Sigma\left\{\left(\mathrm{S}_{\mathrm{t}}\right)_{\mathrm{m}} * \mathrm{p}_{\mathrm{m}}\right\}\left[\left(\mathrm{S}_{\mathrm{t}}\right)_{\mathrm{m}}=\left\{\mathrm{E}\left(\mathrm{s}_{\mathrm{t}}\right) *\left(\mathrm{q}_{\mathrm{t}}\right)_{\mathrm{m}}\right\}=\left\{\left(\mathrm{s}_{\mathrm{t}}\right)_{\mathrm{m}} *\left(\mathrm{q}_{\mathrm{t}}\right)_{\mathrm{m}}\right\}\right] ;$

$\mathrm{E}\left(\mathrm{C}_{\mathrm{t}}\right)=\Sigma\left\{\left(\mathrm{C}_{\mathrm{t}}\right)_{\mathrm{m}} * \mathrm{p}_{\mathrm{m}}\right\} \quad\left[\left(\mathrm{C}_{\mathrm{t}}\right)_{\mathrm{m}}=\left\{\mathrm{E}\left(\mathrm{c}_{\mathrm{t}}\right) *\left(\mathrm{q}_{\mathrm{t}}\right)_{\mathrm{m}}\right\}=\left\{\left(\mathrm{c}_{\mathrm{t}}\right)_{\mathrm{m}} *\left(\mathrm{q}_{\mathrm{t}}\right)_{\mathrm{m}}\right\}\right] ;$

$\mathrm{E}\left(\mathrm{OE}_{\mathrm{t}}\right)=\Sigma\left\{\left(\mathrm{OE}_{\mathrm{t}}\right)_{\mathrm{m}} * \mathrm{p}_{\mathrm{m}}\right\}\left[\left(\mathrm{OE}_{\mathrm{t}}\right)_{\mathrm{m}}=\left\{\left(\mathrm{C}_{\mathrm{t}}\right)_{\mathrm{m}}-\mathrm{E}\left(\mathrm{F}_{\mathrm{t}}\right)\right\}\right] ;$

$\mathrm{E}\left(\operatorname{RONOA}_{\mathrm{t}}\right)=\Sigma\left\{\left(\operatorname{RONOA}_{\mathrm{t}}\right)_{\mathrm{m}} * \mathrm{p}_{\mathrm{m}}\right\}\left[\left\{\left(\operatorname{RONOA}_{\mathrm{t}}\right)_{\mathrm{m}}=\left\{\left(\mathrm{OE}_{\mathrm{t}}\right)_{\mathrm{m}} / \mathrm{E}\left(\mathrm{ANOA}_{\mathrm{t}}\right)\right\}\right] ;\right.$

$\mathrm{E}\left(\mathrm{ANOA}_{\mathrm{t}}\right)=\left[\left\{\mathrm{NOA}_{0}+\mathrm{E}\left(\mathrm{NOA}_{\mathrm{t}}\right)\right\} / 2\right]\left\{\mathrm{NOA}_{0}=\right.$ opening NOA (at time ' 0 ' $\left.)\right\} ;$

$\mathrm{E}\left(\operatorname{NOATR}_{\mathrm{t}}\right)=\Sigma\left\{\left(\operatorname{NOATR}_{\mathrm{t}}\right)_{\mathrm{m}} * \mathrm{p}_{\mathrm{m}}\right\}\left[\left(\operatorname{NOATR}_{\mathrm{t}}\right)_{\mathrm{m}}=\left\{\left(\mathrm{S}_{\mathrm{t}}\right)_{\mathrm{m}} / \mathrm{E}\left(\mathrm{ANOA}_{\mathrm{t}}\right)\right\}\right] ;$

$\mathrm{E}\left(\mathrm{ANOA}_{\mathrm{t}}\right), \mathrm{E}\left(\mathrm{s}_{\mathrm{t}}\right), \mathrm{E}\left(\mathrm{v}_{\mathrm{t}}\right), \mathrm{E}\left(\mathrm{c}_{\mathrm{t}}\right)$ \{ hence $\left.\mathrm{E}\left(\mathrm{r}_{\mathrm{t}}\right)\right\}$ and $\mathrm{E}\left(\mathrm{F}_{\mathrm{t}}\right)$ are assumed to remain constant in the above functional relationships .

Hereafter the subscript ' $t$ ' will be ignored in order to avoid complexities in the formulations.

CASE $1:$ I FV $=q$, DFV $=$ OE

Under condition of future business risk the initial values of $\mathrm{OE}$ and $\mathrm{q}$ will be $\mathrm{E}(\mathrm{OE})$ and $\mathrm{E}$ ( q ) respectively, and the ex - ante $\mathrm{DOL}_{\mathrm{E}}$ [ akin to IMA \{vide eq. (4) \} of a physical lever ] is given from eq. ( 21$)$ as :

$D_{\tilde{O}} \mathrm{~L}_{\mathrm{E}}=\frac{\mid \text { Expected percentage change in } \mathrm{OE}_{\mathrm{m}} \text { from } \mathrm{E}(\mathrm{OE})\{\neq 0\} \mid}{\mid \text { Expected percentage change in } \mathrm{q}_{\mathrm{m}} \text { from } \mathrm{E}(\mathrm{q})\{\neq 0\} \mid}$

If the expected percentage change in $\mathrm{E}(\mathrm{q})$ is $1 \%$ [ i.e. if the actual 'end - of - the period' value of $\mathrm{q}$ is expected to be $1 \%$ more or $1 \%$ less than $\mathrm{E}(\mathrm{q})]$ then the corresponding expected percentage change in the actual value of $\mathrm{OE}$ from $\mathrm{E}(\mathrm{OE})$ is measured by DÕLE, ceteris paribus .

Now, for the absolute value of a finite change in $\mathrm{q}_{\mathrm{m}}$ from $\mathrm{E}(\mathrm{q})\left\{\left|\Delta \mathrm{q}_{\mathrm{m}}\right|\right\}$

$\left[=\left|q_{m}-E(q)\right|\right]$, we get the absolute value of the finite change in $\mathrm{OE}_{\mathrm{j}}$ from $\mathrm{E}(\mathrm{OE})$, ceteris paribus $[\mathrm{E}(\mathrm{s}), \mathrm{E}(\mathrm{v})\{$ hence $\mathrm{E}(\mathrm{c})\}$ and $\mathrm{E}(\mathrm{F})$ held constant], from eq. (31) as :

$\left|\Delta \mathrm{OE}_{\mathrm{m}}\right|=\left|\mathrm{OE}_{\mathrm{m}}-\mathrm{E}(\mathrm{OE})\right|=\mathrm{E}(\mathrm{c}) *\left|\Delta \mathrm{q}_{\mathrm{m}}\right|$

$\left|\Delta \mathrm{q}_{\mathrm{m}}\right|$ and $\left|\Delta \mathrm{OE}_{\mathrm{m}}\right|$ being random variables with respective expected values

$\mathrm{E}(|\Delta \mathrm{q}|)=\Sigma\left\{\left|\Delta \mathrm{q}_{\mathrm{m}}\right| * \mathrm{p}_{\mathrm{m}}\right\}$ and $\mathrm{E}(|\Delta \mathrm{OE}|)=\Sigma\left\{\left|\Delta \mathrm{OE}_{\mathrm{m}}\right| * \mathrm{p}_{\mathrm{m}}\right\}$

[ since $\mathrm{p}_{\mathrm{m}}>0$ ].

The absolute value of the percentage change in $\mathrm{q}_{\mathrm{m}}$ from $\mathrm{E}(\mathrm{q})$ and the absolute value of the percentage change in $\mathrm{OE}_{\mathrm{m}}$ from $\mathrm{E}(\mathrm{OE})$ given by :

$\left|\% \Delta \mathrm{q}_{\mathrm{m}}\right|=\left|\left\{\Delta \mathrm{q}_{\mathrm{m}} / \mathrm{E}(\mathrm{q})\right\} * 100\right|$

$\left|\% \Delta \mathrm{OE}_{\mathrm{m}}\right|=\left|\left\{\Delta \mathrm{OE}_{\mathrm{m}} / \mathrm{E}(\mathrm{OE})\right\} * 100\right|$

are also random variables with respective expected values :

$\mathrm{E}(|\% \Delta \mathrm{q}|)=\{\mathrm{E}(|\Delta \mathrm{q}|) / \mathrm{E}(\mathrm{q})\} * 100[$ since $\mathrm{E}(\mathrm{q})>0]$

$\mathrm{E}(|\% \Delta \mathrm{OE}|)=\{\mathrm{E}(|\Delta \mathrm{OE}|) /|\mathrm{E}(\mathrm{OE})|\} * 100$

Taking expectations of both sides of eq. (34) we get :

$\mathrm{E}(\Delta \mathrm{OE})=\mathrm{E}(\mathrm{c}) * \mathrm{E}(\Delta \mathrm{q})$

From eqs. (33), (37), ( 38$)$ \& ( 39 ) we get : 
DÕ $_{\mathrm{E}}=\{|\mathrm{E}(\% \Delta \mathrm{OE})| /|\mathrm{E}(\% \Delta \mathrm{q})|\}$, or

$\operatorname{DOOL}_{\mathrm{E}}=\{\mathrm{E}(|(\Delta \mathrm{OE})|) /|\mathrm{E}(\mathrm{OE})|\} /\{\mathrm{E}(|(\Delta \mathrm{q})|) / \mathrm{E}(\mathrm{q})\}$, or

$\mathrm{DO}_{\mathrm{E}}=[\{\mathrm{E}(\mathrm{c}) * \mathrm{E}(\mathrm{q})\} /|\mathrm{E}(\mathrm{OE})|]=\{\mathrm{E}(\mathrm{C}) /|\mathrm{E}(\mathrm{OE})|\}$

Eqs. ( 22 ) \& ( 40 ) being similar with the initial values being replaced by the expected values, the other formulations under conditions of future business risk would be similar to that obtained in the preceding section with expected values being replaced with the initial values .

CASE 2 : I FV = S , DFV = OE

Results of CASE 1 will be obtained by replacing :

(i) $\mathrm{q}$ with $\mathrm{S}$ and (ii) $\mathrm{c}$ with $\mathrm{r}$.

CASE 3 : I FV = NOATR, DFV = RONOA

Results of CASE 1 will be obtained by replacing :

(i) $\mathrm{q}$ with NOATR, (ii) OE with RONOA and (iii) $\mathrm{c}$ with $(\mathrm{r} *$ ANOA).

\subsection{OPERATING LEVERAGE RISK}

The 'risk' which is traditionally said to be directly affected by operating leverage of a business firm , ceteris paribus, is known as 'operating risk' and based on the ' stand - alone risk framework, ${ }^{14}$ ( which ignores the benefits of shareholder diversification ) it is defined as the variability ( considering both favourable and unfavourable outcomes ) of Operating Earnings ( OE ) from its expected value due to the risk inherent in the normal business operations of the firm. The common statistical measures of such risk are :

(a) in absolute terms, the variance $\left(\sigma^{2}\right)$ or the standard deviation $(\sigma)$ of $\mathrm{OE}$, and

(b) in relative terms, the :

(i) absolute value ( modulus) of the coefficient of variation (CV) [ i.e. the ratio of standard deviation to the absolute value of $\mathrm{E}(\mathrm{OE})\{$ since $\mathrm{E}(\mathrm{OE})$ may be negative $\}$ ], or

(ii) absolute value of the ratio of mean absolute deviation (MAD) to the expected value of $\mathrm{OE}$ [i.e. ratio of $\mathrm{MAD}$ to the absolute value of $\mathrm{E}(\mathrm{OE})$ ] .

However, the 'risk' which may be said to be associated with operating leverage of a business firm may be termed as 'operating leverage risk' ( OLR ) and based on the 'stand-alone risk framework' it may be defined as the magnified relative variability of OE ( or RONOA) [ from $\mathrm{E}(\mathrm{OE})\{$ or $\mathrm{E}(\mathrm{RONOA})\}$ ] in response to a relative variability of $\mathrm{q}$ or $\mathrm{S}$ ( or NOATR) [ from $\mathrm{E}(\mathrm{q})$ or $\mathrm{E}(\mathrm{S})\{$ or $\mathrm{E}(\mathrm{NOATR})\}$ ], in the presence of an operating account structural plan whose components are assumed to remain constant in the functional relationship between $\mathrm{E}(\mathrm{OE})$ $\{$ or $\mathrm{E}(\mathrm{RONOA})\}$ and $\mathrm{E}(\mathrm{q})$ or $\mathrm{E}(\mathrm{S})\{$ or $\mathrm{E}(\mathrm{NOATR})\}$, considering both favourable and unfavourable situations of operating leverage under condition of future business risk .

CASE $1:$ IFV $=q$, DFV $=$ OE

The statistical measure of OLR under the 'stand-alone risk framework' is given as:

| Coefficient of variation $(\mathrm{CV})$ of $\mathrm{OE} \mid$

( a ) OLR =

$$
\text { Coefficient of variation ( C V ) of } \mathrm{q}
$$

$$
\text { Mean absolute deviation (MAD) of } \mathrm{OE} /|\mathrm{E}(\mathrm{OE})|
$$

$\{$ Mean absolute deviation (MAD) of $\mathrm{q} / \mathrm{E}(\mathrm{q})$ \}

If $\sigma_{\mathrm{OE}}$ and $\sigma_{\mathrm{q}}$ be the standard deviations of $\mathrm{OE}$ and $\mathrm{q}$ respectively then from eq. (31), ceteris paribus [ $\mathrm{E}(\mathrm{c})$ held constant ], we get :

$\sigma_{\mathrm{OE}}=\mathrm{E}(\mathrm{c}) * \sigma_{\mathrm{q}}$

and from eqs. ( 41$) \&(43)$ we get :

$\mathrm{OLR}=\frac{|\mathrm{CV}(\mathrm{OE})|}{\mathrm{CV}(\mathrm{q})}=\frac{\left\{\sigma_{\mathrm{OE}} /|\mathrm{E}(\mathrm{OE})|\right\}}{\left\{\sigma_{\mathrm{q}} / \mathrm{E}(\mathrm{q})\right\}}$

$\mathrm{OLR}=[\{\mathrm{E}(\mathrm{c}) * \mathrm{E}(\mathrm{q})\} /|\mathrm{E}(\mathrm{OE})|]=\mathrm{DÕL}_{\mathrm{E}}[$ vide eq. $(40)]$

14 'Stand-alone risk' ( or 'total risk') is directly related to its components 'systematic risk' ( beta coefficient) and 'unsystematic risk' (or 'idiosyncratic risk'). 
Now, $\operatorname{MAD}(\mathrm{OE})=\mathrm{E}\left(\left|\mathrm{OE}_{\mathrm{m}}-\mathrm{E}(\mathrm{OE})\right|\right)$ and $\operatorname{MAD}(\mathrm{q})=\mathrm{E}\left(\left|\mathrm{q}_{\mathrm{m}}-\mathrm{E}(\mathrm{q})\right|\right)$ and from eq. (34) we get :

$\operatorname{MAD}(\mathrm{OE})=\mathrm{E}(\mathrm{c}) * \operatorname{MAD}(\mathrm{q})$

So from eqs. ( 42$) \&(45)$ we get :

$\mathrm{OLR}=\frac{\{\operatorname{MAD}(\mathrm{OE}) /|\mathrm{E}(\mathrm{OE})|\}}{\{\operatorname{MAD}(\mathrm{q}) / \mathrm{E}(\mathrm{q})\}}$, or

$\mathrm{OLR}=\{\mathrm{E}(\mathrm{c}) * \mathrm{E}(\mathrm{q}) /|\mathrm{E}(\mathrm{OE})|\}=\mathrm{DÕL}_{\mathrm{E}} \quad[$ vide eq. $(40)]$

( 46 )

Hence $D O \tilde{L} L_{E}$ is a measure of operating leverage risk.

The components of operating leverage risk (OLR) may be said to be :

(1) 'Downside Operating Leverage Risk' ( DOLR) representing the unfavourable situation [ i.e. magnified expected percentage decrease in $\mathrm{OE}$ from $\mathrm{E}(\mathrm{OE})$ for an expected one percentage decrease in $\mathrm{q}$ from $\mathrm{E}(\mathrm{q})$ ] of operating leverage, measured by the :

(i) ratio of $\mathrm{CV}(\mathrm{OE})\{$ considering values of $\mathrm{OE}<\mathrm{E}(\mathrm{OE})\}$ to $\mathrm{CV}(\mathrm{q})\{$ considering values of $\mathrm{q}<\mathrm{E}(\mathrm{q})\}$ given as :

$\operatorname{DOLR}=\frac{\mathrm{CV}(\mathrm{OE})_{[\mathrm{OE}<\mathrm{E}(\mathrm{OE})]} \mathrm{CV}(\mathrm{q})_{[\mathrm{q}<\mathrm{E}(\mathrm{q})]}}{\left\{\sigma_{\mathrm{OE}}[\mathrm{OE}<\mathrm{E}(\mathrm{OE})] / \mathrm{E}(\mathrm{OE}) \mid\right\}}$

$\operatorname{DOLR}=[\{\mathrm{E}(\mathrm{c}) * \mathrm{E}(\mathrm{q})\} /|\mathrm{E}(\mathrm{OE})|]=\mathrm{DÕL}_{\mathrm{E}} \quad[$ vide eq. $(40)]$

$\left[\right.$ since $\left\{\sigma_{\mathrm{OE}}[\mathrm{OE}<\mathrm{E}(\mathrm{OE})] /\left\{\sigma_{\mathrm{q}[\mathrm{q}<\mathrm{E}(\mathrm{q})]}\right\}=\mathrm{E}(\mathrm{c})\right]$,

where $\sigma_{\mathrm{OE}[\mathrm{OE}<\mathrm{E}(\mathrm{OE})]}$ is the "downside semi-standard deviation' of $\mathrm{OE}$ and $\sigma_{\mathrm{q}}[\mathrm{q}<\mathrm{E}(\mathrm{q})]$ is the 'downside semi-standard deviation' of $\mathrm{q}$;

(ii) ratio of $[\mathrm{MAD}(\mathrm{OE})\{$ considering values of $\mathrm{OE}<\mathrm{E}(\mathrm{OE})\} / \mathrm{E}(\mathrm{OE})\}$ to $[\operatorname{MAD}(\mathrm{q})$ $\{$ considering values of $\mathrm{q}<\mathrm{E}(\mathrm{q})\} / \mathrm{E}(\mathrm{q})]$ given as :

$\operatorname{DOLR}=\frac{\operatorname{MAD}(\mathrm{OE}){ }_{[\mathrm{OE}<\mathrm{E}(\mathrm{OE})]} /|\mathrm{E}(\mathrm{OE})|}{\operatorname{MAD}(\mathrm{q})_{[\mathrm{q}<\mathrm{E}(\mathrm{q})]} / \mathrm{E}(\mathrm{q})}$, or

$\operatorname{DOLR}=[\mathrm{E}(\mathrm{c}) * \mathrm{E}(\mathrm{q}) /|\mathrm{E}(\mathrm{OE})|]=\mathrm{DÕL}_{\mathrm{E}} \quad[$ vide eq. $(40)]$

$\left[\right.$ since $\left.\left.\left.\left\{\operatorname{MAD}(\mathrm{OE})_{[\mathrm{OE}}<\mathrm{E}(\mathrm{OE})\right]\right\} \operatorname{MAD}(\mathrm{q})_{[\mathrm{q}<\mathrm{E}(\mathrm{q})]}\right\}=\mathrm{E}(\mathrm{c})\right]$

where $\operatorname{MAD}(\mathrm{OE})_{[\mathrm{OE}<\mathrm{E}(\mathrm{OE})]}$ is the ' downside $\mathrm{MAD}$ ' of $\mathrm{OE}$, and

$\operatorname{MAD}(q)_{[q<E(q)]}$ is the 'downside MAD' of $q$.

( 2 ) 'Upside Operating Leverage Risk' ( UOLR) representing the favourable situation [i.e. magnified expected percentage increase in $\mathrm{OE}$ from $\mathrm{E}(\mathrm{OE})$ for an expected one percentage increase in $\mathrm{q}$ from $\mathrm{E}(\mathrm{q})]$ of operating leverage, measured by the :

(i) ratio of $\mathrm{CV}(\mathrm{OE})\{$ considering values of $\mathrm{OE} \geq \mathrm{E}(\mathrm{OE})\}$ to $\mathrm{CV}(\mathrm{q})\{$ considering values of $\mathrm{q}$ $\geq \mathrm{E}(\mathrm{q})\}$ and given as :

$\operatorname{UOLR}=\frac{\mathrm{CV}(\mathrm{OE})_{[\mathrm{OE} \geq \mathrm{E}(\mathrm{OE})]}}{\mathrm{CV}(\mathrm{q})_{[\mathrm{q} \geq \mathrm{E}(\mathrm{q})]}}=\frac{\left\{\boldsymbol{\sigma}_{\mathrm{OE}[\mathrm{OE} \geq \mathrm{E}(\mathrm{OE})]} /|\mathrm{E}(\mathrm{OE})|\right\}}{\left\{\sigma_{\mathrm{q}[\mathrm{q} \geq \mathrm{E}(\mathrm{q})]} / \mathrm{E}(\mathrm{q})\right\}}$

$\mathrm{UOLR}=[\{\mathrm{E}(\mathrm{c}) * \mathrm{E}(\mathrm{q})\} /|\mathrm{E}(\mathrm{OE})|]=\mathrm{DÕL}_{\mathrm{E}}[$ vide eq. $(40)]$

$\left[\right.$ since $\left.\left\{\sigma_{\mathrm{OE}[\mathrm{OE} \geq \mathrm{E}(\mathrm{OE})]} / \sigma_{\mathrm{q}[\mathrm{q} \geq \mathrm{E}(\mathrm{q})]}\right\}=\mathrm{E}(\mathrm{c})\right]$

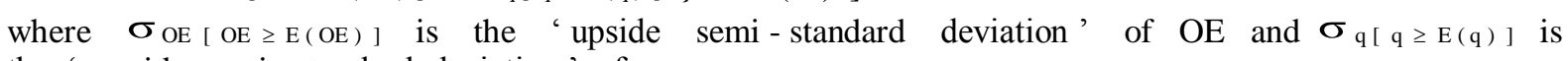
the ' upside semi - standard deviation' of $\mathrm{q}$;

(ii) ratio of $[\mathrm{MAD}(\mathrm{OE})\{$ considering values of $\mathrm{OE} \geq \mathrm{E}(\mathrm{OE})\} / \mathrm{E}(\mathrm{OE})\}$ to $[\operatorname{MAD}(\mathrm{q})$ $\{$ considering values of $\mathrm{q} \geq \mathrm{E}(\mathrm{q})\} / \mathrm{E}(\mathrm{q})]$ given as : 


$\mathrm{MAD}(\mathrm{OE})_{[\mathrm{OE} \geq \mathrm{E}(\mathrm{OE})]} /|\mathrm{E}(\mathrm{OE})|$
$\mathrm{UOLR}=$
$\mathrm{MOLR}(\mathrm{q})_{[\mathrm{q} \geq \mathrm{E}(\mathrm{q})] / \mathrm{E}(\mathrm{q})}=[\mathrm{E}(\mathrm{c}) * \mathrm{E}(\mathrm{q}) /|\mathrm{E}(\mathrm{OE})|]=\mathrm{DOOL} \mathrm{L}_{\mathrm{E}} \quad[$ vide eq. $(40)]$

$\left[\right.$ since $\left.\left\{\operatorname{MAD}(\mathrm{OE})_{[\mathrm{OE} \geq \mathrm{E}(\mathrm{OE})]} / \operatorname{MAD}(\mathrm{q})_{[\mathrm{q} \geq \mathrm{E}(\mathrm{q})]}\right\}=\mathrm{E}(\mathrm{c})\right]$

where $\operatorname{MAD}(\mathrm{OE})[\mathrm{OE} \geq \mathrm{E}(\mathrm{OE})]$ is the ' upside $\mathrm{MAD}$ ' of $\mathrm{OE}$ and

$\left.\operatorname{MAD}(\mathrm{q})_{[\mathrm{q} \geq \mathrm{E}(\mathrm{q})]}\right]$ is the 'upside MAD' of $\mathrm{q}$.

Hence DÕ $L_{E}$ is a measure of 'operating leverage risk' as well as its two components 'Downside Operating Leverage Risk' ( DOLR) and 'Upside Operating Leverage Risk'(UOLR).

\subsection{DECISION CRITERION UNDER CONDITION OF OPERATING LEVERAGE RISK}

A decision - criterion based on the concept of 'expected utility', considering the relative importance of the two components of 'Operating Leverage Risk' to the decision-maker may be formulated .

A rational decision - maker may be said to be fully ( 100 percent ):

(a) 'DOLR averse' if he or she does not like DOLR at all while being indifferent to UOLR [ i.e. $100 \%$ importance is given to DOLR and no importance is given to UOLR ] ;

(b) 'UOLR affine' if he or she only likes UOLR while being indifferent to DOLR [ i.e. $100 \%$ importance is given to UOLR and no importance is given to DOLR .

So , the degree of 'downside risk averseness' or 'upside risk affinity' will lie between $0 \%$ to $100 \%$. For example, a decision - maker may be $60 \%$ 'DOLR averse' and $40 \%$ 'UOLR affine' i.e. he or she subjectively assigns "DOLR averseness' 1.5 times more importance than "UOLR affinity',

However, no rational decision - maker may be believed to be (to any degree) :

(a) 'DOLR affine' i.e. he or she likes DOLR to any degree, or

(b) 'UOLR averse' i.e. he or she dislikes UOLR to any degree .

Assuming that the degrees of DOLR averseness and UOLR affinity subjectively assigned by the decision-maker are $\alpha \%(0<\alpha<100)$ and $\beta \%\{\beta=(100-\alpha)\}$ respectively, the linear utility functions of DÕL $\mathrm{E}_{\mathrm{E}}$ for DOLR and UOLR scenarios \{ DOLR and UOLR scenarios giving rise to disutility ( or negative utility) and (positive) utility respectively \} based on a ratio scale ( representing the relative importance DOLR and UOLR scenarios) may be given as :

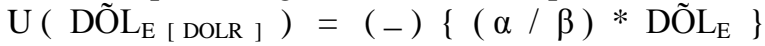

$\mathrm{U}\left(\mathrm{DÕL} \mathrm{L}_{\mathrm{E}}[\right.$ UOLR ] $)=(\beta / \alpha) *$ DÕL $\mathrm{L}_{\mathrm{E}}$

where DÕ $\mathrm{L}_{\mathrm{E}}[\mathrm{DOLR}]=\mathrm{DO} \mathrm{L}_{\mathrm{E}}[$ UOLR $]=\mathrm{DÕL} \mathrm{L}_{\mathrm{E}}$, and

the unit of measurement of utility of DÕ $\mathrm{L}_{\mathrm{E}}$ is the hypothetical unit 'util'.

The expected value of $\mathrm{U}\left(\mathrm{DO} \mathrm{L}_{\mathrm{E}}\right)$ is then given by :

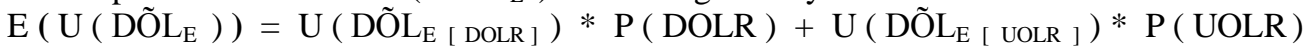

where $\mathrm{P}(\mathrm{DOLR})$ and $\mathrm{P}(\mathrm{UOLR})$ are the probabilities of occurrences of DOLR and UOLR scenarios respectively given by :

$P(D O L R)=P(q<E(q))=P(O E<E(O E))$

$P(\operatorname{UOLR})=P(q \geq E(q))=P(O E \geq E(O E))$

Now, $\mathrm{E}\left(\mathrm{U}\left(\mathrm{DOO} \mathrm{L}_{\mathrm{E}}\right)\right.$ ) may be positive ( denoting net utility) or negative (denoting net disutility). If $\mathrm{E}\left(\mathrm{U}\left(\mathrm{DO} \mathrm{L}_{\mathrm{E}}\right)\right)>0$, then the 'principle of maximization of expected utility' is to be followed. If $\mathrm{E}\left(\mathrm{U}\left(\mathrm{DO} \mathrm{L}_{\mathrm{E}}\right)\right)<0$, then absolute value of $\mathrm{E}\left(\mathrm{U}\left(\mathrm{DO} \mathrm{L}_{\mathrm{E}}\right)\right)$ is to be considered, the decision rule being the 'principle of minimization of the absolute value of expected disutility'.

A decision - maker will be said to be indifferent between the DOLR and the UOLR scenarios when $\mathrm{E}\left(\mathrm{U}\left(\mathrm{DO} \mathrm{L}_{\mathrm{E}}\right)\right)=0$ i.e. when $\alpha=\beta$ and $\mathrm{P}(\mathrm{DOLR})=\mathrm{P}(\mathrm{UOLR})$.

CASE 2 : IFV $=S$, DFV $=$ OE

Results of CASE 1 will be obtained by replacing :

(i) $\mathrm{q}$ with $\mathrm{S}$, and (ii) $\mathrm{c}$ with $\mathrm{r}$.

CASE 3 : I FV = NOATR, DFV = RONOA

Results of CASE 1 will be obtained by replacing :

(i ) $\mathrm{q}$ with NOATR, (ii) OE with RONOA, and (iii ) $\mathrm{c}$ with $(\mathrm{r} *$ ANOA ). 


\section{Intra-Firm Operating Leverage Analysis}

obtain :

Extending further the analogy between physical leverage and operating leverage (page 6 ) we

(h) mutually dependent alternative physical scenarios of the physical fulcrum (PF) with its varying relative position $\approx$ mutually dependent alternative operating account structural plans (OASP s) with varying relative proportion of fixed operating $\operatorname{cost}(\mathrm{F})$.

The intra - firm operating leverage analysis involves the following steps :

(1) Conducting ex - ante analysis at the beginning of a short-term planning horizon by:

(a) calculating $\mathrm{E}(\mathrm{q})$ for the period ;

( $b$ ) considering mutually dependent alternative 'Operating Account Structural Plans' (OASP s ) with varying ' relative proportion of $\mathrm{E}(\mathrm{F})$ ' [ i.e. varying $\mathrm{E}(\mathrm{F})$ and $\mathrm{E}(\mathrm{v})$ in the operating cost structures or varying $\mathrm{E}(\mathrm{F})$ and $\mathrm{E}(\mathrm{V})\{\mathrm{E}(\mathrm{T})$ remaining unchanged with full substitutability of $\mathrm{E}(\mathrm{F})$ for $\mathrm{E}(\mathrm{V})\}$ in the total operating cost structures, at a given level of $\mathrm{E}(\mathrm{q})]$ with $\mathrm{E}$ ( NOA ), $\mathrm{E}(\mathrm{s})$ and $\mathrm{E}(\mathrm{S})$ remaining unchanged, yielding equivalent $\mathrm{E}(\mathrm{OE})\{$ or $\mathrm{E}$ ( RONOA ) $\}$, so that the decision - maker is apparently indifferent between the alternative OASP $\mathrm{s}$ based on earnings ( or return );

(c) calculating DÕL $\mathrm{L}_{\mathrm{E}}$ ( a measure of operating leverage risk ) for each of the alternative OASP s ; [ If we consider two alternative OASP s ' $A$ ' and ' $B$ ' with varying $E(F)$ and $E(v)\{$ such that $\mathrm{E}(\mathrm{F})_{\mathrm{B}}>\mathrm{E}(\mathrm{F})_{\mathrm{A}}$ and $\left.\mathrm{E}(\mathrm{v})_{\mathrm{B}}<\mathrm{E}(\mathrm{v})_{\mathrm{A}}\right\}, \mathrm{E}(\mathrm{s})$ and $\mathrm{E}(\mathrm{NOA})$ remaining unchanged $\{$ so that $\left.\mathrm{E}(\mathrm{c})_{\mathrm{B}}>\mathrm{E}(\mathrm{c})_{\mathrm{A}}\right\}$.

At a calculated value of $E(q)$ :

$\mathrm{E}(\mathrm{V})_{\mathrm{B}}<\mathrm{E}(\mathrm{V})_{\mathrm{A}} ; \mathrm{E}(\mathrm{T})_{\mathrm{B}}=\mathrm{E}(\mathrm{T})_{\mathrm{A}} ; \mathrm{E}(\mathrm{S})_{\mathrm{A}}=\mathrm{E}(\mathrm{S})_{\mathrm{B}} ; \mathrm{E}(\mathrm{C})_{\mathrm{B}}>\mathrm{E}(\mathrm{C})_{\mathrm{A}} ;$

$\mathrm{E}(\mathrm{OE})_{\mathrm{B}}=\mathrm{E}(\mathrm{OE})_{\mathrm{A}} ; \mathrm{DO} \mathrm{L}_{\mathrm{E}_{(\mathrm{B})}}>\mathrm{DO}_{\mathrm{L}_{\mathrm{E}}}$ A $)$.

The relationships between $\mathrm{E}(\mathrm{v})_{\mathrm{A}}$ and $\mathrm{E}(\mathrm{v})_{\mathrm{B}}$, and $\mathrm{E}(\mathrm{F})_{\mathrm{A}}$ and $\mathrm{E}(\mathrm{F})_{\mathrm{B}}$ are obtained as follows :

Since $\mathrm{E}(\mathrm{T})_{\mathrm{A}}=\mathrm{E}(\mathrm{T})_{\mathrm{B}}$, we get :

$\left\{\mathrm{E}(\mathrm{v})_{\mathrm{A}} * \mathrm{E}(\mathrm{q})\right\}+\mathrm{E}(\mathrm{F})_{\mathrm{A}}=\left\{\mathrm{E}(\mathrm{v})_{\mathrm{B}} * \mathrm{E}(\mathrm{q})\right\}+\mathrm{E}(\mathrm{F})_{\mathrm{B}}$, or

$\mathrm{E}(\mathrm{v})_{\mathrm{B}}=\mathrm{E}(\mathrm{v})_{\mathrm{A}}-\left[\left\{\mathrm{E}(\mathrm{F})_{\mathrm{B}}-\mathrm{E}(\mathrm{F})_{\mathrm{A}}\right\} / \mathrm{E}(\mathrm{q})\right]$

or $\mathrm{E}(\mathrm{F})_{\mathrm{B}}=\mathrm{E}(\mathrm{F})_{\mathrm{A}}+\left[\left\{\mathrm{E}(\mathrm{v})_{\mathrm{A}}-\mathrm{E}(\mathrm{v})_{\mathrm{B}}\right\} * \mathrm{E}(\mathrm{q})\right] \quad$ (57) $]$; and

(d) choosing an OASP based on the principle of maximization of expected utility \{ or principle of minimization of the absolute value of expected disutility (negative utility) $\}$ of DÕL $\mathrm{E}_{\mathrm{E}}$, considering the degrees of 'downside operating leverage risk' ( DOLR) averseness and ' upside operating leverage risk' ( UOLR ) affinity, subjectively assigned by the decision - maker .

( 2 ) Conducting ex-post analysis for the chosen OASP at the end of the period considering the revised expected values of OE ( or RONOA) and S ( or NOATR) based on the actual value of $q$ ( the primary independent financial variable), ceteris paribus, by :

(A) Calculating ex - post $\mathrm{DOL}_{\mathrm{E}}[$ akin to AMA \{vide eq. (2) $\}$ of a physical lever ] form eq. ( 20 ) as :

| Percentage change in the revised expected value $(\neq 0)$ of

OE ( or RONOA ) \{ based on the actual value of $q\}$ |

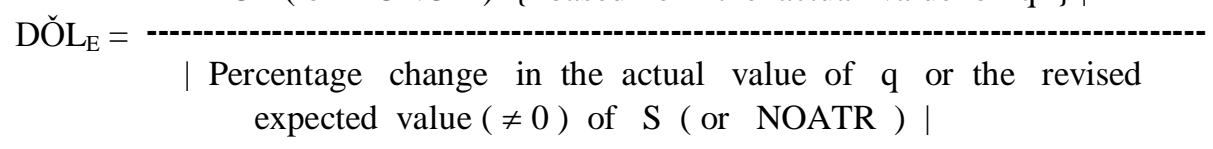

The 'revised expected values' of $\mathrm{S}, \mathrm{T}, \mathrm{V}, \mathrm{C}, \mathrm{OE}, \mathrm{NOATR}$ and RONOA considering the actual value of $\mathrm{q}[\mathrm{A}(\mathrm{q})]$, ceteris paribus $\{\mathrm{E}(\mathrm{s}), \mathrm{E}(\mathrm{v}), \mathrm{E}(\mathrm{c}), \mathrm{E}(\mathrm{r})$ and $\mathrm{E}(\mathrm{ANOA})$ remaining constant $\}$, is given from eqs. (29), (30), (31) \& (32) as :

$\mathrm{RE}(\mathrm{S})=\mathrm{E}(\mathrm{s}) * \mathrm{~A}(\mathrm{q})$

$\mathrm{RE}(\mathrm{T})=\mathrm{E}(\mathrm{V})+\mathrm{E}(\mathrm{F})=\mathrm{E}(\mathrm{v}) * \mathrm{~A}(\mathrm{q})+\mathrm{E}(\mathrm{F})$

$\mathrm{RE}(\mathrm{OE})=\mathrm{RE}(\mathrm{C})-\mathrm{E}(\mathrm{F})=\mathrm{E}(\mathrm{c}) * \mathrm{~A}(\mathrm{q})-\mathrm{E}(\mathrm{F})=\mathrm{E}(\mathrm{r}) * \mathrm{RE}(\mathrm{S})-\mathrm{E}(\mathrm{F})$

$\mathrm{RE}(\mathrm{RONOA})=\mathrm{E}(\mathrm{r}) * \mathrm{RE}(\mathrm{NOATR})-\{\mathrm{E}(\mathrm{F}) / \mathrm{E}(\mathrm{ANOA})\}$

CASE 1: I FV $=q$, DFV $=$ OE

For the absolute value of an actual finite change in $A(q)\{|\Delta A(q)|\}$ given by $[|\Delta \mathrm{A}(\mathrm{q})|=|\mathrm{E}(\mathrm{q})-\mathrm{A}(\mathrm{q})|]$ the absolute value of the finite change in $\mathrm{RE}(\mathrm{OE})$, ceteris paribus, is given from eqs. ( 31 ), (61) \& (63) as : 
$|\Delta \mathrm{RE}(\mathrm{OE})|=|\mathrm{E}(\mathrm{OE})-\mathrm{RE}(\mathrm{OE})|=\mathrm{E}(\mathrm{c}) *|\Delta \mathrm{A}(\mathrm{q})|$

From eqs. ( 56$) \&(62)$ we get the ex-post $\mathrm{DOL}_{\mathrm{E}}$ as :

$\mathrm{DOCL}_{\mathrm{E}}=\{|\Delta \mathrm{RE}(\mathrm{OE})| /|\mathrm{RE}(\mathrm{OE})|\} /\{|\Delta \mathrm{A}(\mathrm{q})| / \mathrm{A}(\mathrm{q})\}$, or

DǑL $_{\mathrm{E}}=[\{\mathrm{E}(\mathrm{c}) *|\Delta \mathrm{A}(\mathrm{q})|\} /|\mathrm{RE}(\mathrm{OE})|] /\{|\Delta \mathrm{A}(\mathrm{q})| / \mathrm{A}(\mathrm{q})\}$, or

$\mathrm{DOCL}_{\mathrm{E}}=[\{\mathrm{E}(\mathrm{c}) * \mathrm{~A}(\mathrm{q})\} /|\mathrm{RE}(\mathrm{OE})|]=\{\operatorname{RE}(\mathrm{C}) /|\operatorname{RE}(\mathrm{OE})|\}$

CASE $2:$ I FV $=\mathrm{S}, \mathrm{DFV}=\mathrm{OE}$

Results of CASE 1 will be obtained by replacing :

(i) $\mathrm{q}$ with $\mathrm{S}$, ( ii ) $\mathrm{A}(\mathrm{q})$ with $\mathrm{RE}(\mathrm{S})$, and (iii ) c with $\mathrm{r}$.

CASE 3 : IFV = NOATR, DFV = RONOA

Results of CASE 1 will be obtained with the following replacements :

( i ) $q$ with NOATR, ( ii ) A ( q ) with RE ( NOATR), ( iii ) OE with RONOA, and ( iv) c with $(r *$ ANOA ).

( B ) Evaluating the performance of the decision - maker by analyzing the operating leverage efficiency ( OLE ) [ akin to the Efficiency \{ vide eq. (5) \} of a physical lever ] given by:

( a ) For under - estimation [ i.e. DÕL $\mathrm{E}_{\mathrm{E}}<\mathrm{DOCL}_{\mathrm{E}}$ ] :

$\mathrm{OLE}=\left(\mathrm{DO} \mathrm{L}_{\mathrm{E}} / \mathrm{DO} \mathrm{L}_{\mathrm{E}}\right) * 100 \%$

(b ) For over - estimation [ i.e. DÕ $\mathrm{L}_{\mathrm{E}}>\mathrm{DǑL}_{\mathrm{E}}$ ] :

$\mathrm{OLE}=\left(\mathrm{DǑL}_{\mathrm{E}} / \mathrm{DO} \mathrm{L}_{\mathrm{E}}\right) * 100 \%$

The intra - firm operating leverage analysis is illustrated through the following example .

\section{EXAMPLE :}

\section{( I ) EX - ANTE OPERATING LEVERAGE ANALYSIS}

The subjective probability distribution of the possible periodic values of ' $\mathrm{q}$ ' under possible future business scenarios and the calculated values of $\mathrm{E}(\mathrm{q}), \mathrm{CV}(\mathrm{q})$ and $\operatorname{MAD}(\mathrm{q})$ are given below:

TABLE 2 : Probability distribution of ' $q$ '

\begin{tabular}{|c|c|c|c|c|}
\hline $\begin{array}{c}\text { Business } \\
\text { Scenarios }\end{array}$ & $\begin{array}{c}\text { Probability } \\
\left(\mathrm{p}_{\mathrm{m}}\right)\end{array}$ & Range of ' $\mathrm{q}$ ' & $\mathrm{q}_{\mathrm{m}}$ & $\left(\mathrm{q}_{\mathrm{m}} * \mathrm{p}_{\mathrm{m}}\right)$ \\
\hline & & ( Units $)$ & $($ Units $)$ & $($ Units $)$ \\
\hline Very Good & 0.10 & $16,000-20,000$ & 18,000 & 1,800 \\
\hline Good & 0.15 & $12,000-16,000$ & 14,000 & 2,100 \\
\hline Normal & 0.45 & $8,000-12,000$ & 10,000 & 4,500 \\
\hline Bad & 0.25 & $4,000-8,000$ & 6,000 & 1,500 \\
\hline Very Bad & 0.05 & $0-4,000$ & 2,000 & 100 \\
\hline & & & & $\mathbf{E}(\mathbf{q})=\mathbf{1 0 , 0 0 0}$ units \\
\hline
\end{tabular}

TABLE $3:$ CV ( q ) and $\operatorname{MAD}(q)$

\begin{tabular}{|c|c|c|c|}
\hline $\begin{array}{l}\text { Business } \\
\text { Scenarios }\end{array}$ & $\begin{array}{c}\text { Probability } \\
\left(\mathrm{p}_{\mathrm{m}}\right)\end{array}$ & $\mathrm{q}_{\mathrm{m}}-\mathrm{E}(\mathrm{q}) \mid * \mathrm{p}_{\mathrm{m}}$ & $\left\{\mathrm{q}_{\mathrm{m}}-\mathrm{E}(\mathrm{q})\right\}^{2} * \mathrm{p}_{\mathrm{m}}$ \\
\hline & & ( Units ) & ( Units ) [ million ] \\
\hline Very Good & 0.10 & 800 & 6.4 \\
\hline Good & 0.15 & 600 & 2.4 \\
\hline Normal & 0.45 & 0 & 0 \\
\hline Bad & 0.25 & 1,000 & 4 \\
\hline Very Bad & 0.05 & 400 & 3.2 \\
\hline & & MAD $(q)=2,800$ units & $\sigma_{q}^{2}=16$ million units \\
\hline & & $\operatorname{CV}(q)=0.4$ & $\sigma_{q}=4,000$ units \\
\hline
\end{tabular}

Let us consider two mutually dependent OASPs ' $\mathrm{A}$ ' and ' $\mathrm{B}$ ' the particulars of which are given below: 
Operating Leverage Analysis - A Conceptual Framework

TABLE 4 : OASP ' A'

\begin{tabular}{|c|c|c|c|c|c|c|}
\hline \multirow[b]{2}{*}{ Particulars } & \multicolumn{5}{|c|}{ Future Business Scenarios } & \multirow{3}{*}{$\begin{array}{l}\text { Expected } \\
\text { Value }\end{array}$} \\
\hline & $\begin{array}{l}\text { Very } \\
\text { Good }\end{array}$ & Good & Normal & Bad & Very Bad & \\
\hline Probability & 0.10 & 0.15 & 0.45 & 0.25 & 0.05 & \\
\hline & Rs. & Rs. & Rs. & Rs. & Rs. & Rs. \\
\hline NOA [ Rs. ] & $3,60,000$ & $3,60,000$ & $3,60,000$ & $3,60,000$ & $3,60,000$ & $3,60,000$ \\
\hline s [Rs. ] & 20.00 & 20.00 & 20.00 & 20.00 & 20.00 & 20.00 \\
\hline $\begin{array}{lll}\mathrm{V} & \text { [ Rs. ] }\end{array}$ & 12.00 & 12.00 & 12.00 & 12.00 & 12.00 & 12.00 \\
\hline $\mathrm{c}\{=(\mathrm{s}-\mathrm{v})\}[$ Rs. $]$ & 8.00 & 8.00 & 8.00 & 8.00 & 8.00 & 8.00 \\
\hline $\mathrm{r}\{=(\mathrm{c} / \mathrm{s})\}$ & 0.4 & 0.4 & 0.4 & 0.4 & 0.4 & 0.4 \\
\hline $\mathrm{V}\{=(\mathrm{v} * \mathrm{q})\}[\mathrm{Rs}]$. & $2,16,000$ & $1,68,000$ & $1,20,000$ & 72,000 & 24,000 & $1,20,000$ \\
\hline F [ Rs. ] & 40,000 & 40,000 & 40,000 & 40,000 & 40,000 & 40,000 \\
\hline $\mathrm{T}\{=(\mathrm{V}+\mathrm{F})\}[$ Rs. $]$ & $2,56,000$ & $2,08,000$ & $1,60,000$ & $1,12,000$ & 64,000 & $1,60,000$ \\
\hline $\mathrm{S}\{=(\mathrm{s} * \mathrm{q})\}[\mathrm{Rs}]$. & $3,60,000$ & $2,80,000$ & $2,00,000$ & $1,20,000$ & 40,000 & $2,00,000$ \\
\hline $\mathrm{C}\{=(\mathrm{c} * \mathrm{q})\}[$ Rs.] & $1,44,000$ & $1,12,000$ & 80,000 & 48,000 & 16,000 & 80,000 \\
\hline $\mathrm{OE}\{=(\mathrm{C}-\mathrm{F})\}[$ Rs. $]$ & $1,04,000$ & 72,000 & 40,000 & 8,000 & $(-) 24,000$ & 40,000 \\
\hline ANOA $^{\#}$ [Rs. $]$ & $3,20,000$ & $3,20,000$ & $3,20,000$ & $3,20,000$ & $3,20,000$ & $3,20,000$ \\
\hline $\begin{array}{c}\text { NOATR } \\
\{=(\text { S } / \text { ANOA })\} \\
{[\text { times }]}\end{array}$ & 1.125 & 0.875 & 0.625 & 0.375 & 0.125 & 0.625 \\
\hline$\left\{=\left(\begin{array}{c}\text { RONOA } \\
\text { OE } / \text { ANOA })\} \\
* 100 \%\end{array}\right.\right.$ & 32.5 & 22.5 & 12.5 & 2.5 & $(-) 7.5$ & 12.5 \\
\hline $\mathrm{b}_{(\mathrm{q})}\{=(\mathrm{F} / \mathrm{c})\} \quad[$ units $]$ & 5,000 & 5,000 & 5,000 & 5,000 & 5,000 & 5,000 \\
\hline $\mathrm{b}_{(\mathrm{s})}\{=(\mathrm{F} / \mathrm{r})\}[$ Rs. $]$ & $1,00,000$ & $1,00,000$ & $1,00,000$ & $1,00,000$ & $1,00,000$ & $1,00,000$ \\
\hline $\begin{array}{c}\mathrm{b}_{(\text {NOATR })} \\
{[=\{\mathrm{F} /(\mathrm{r} * \text { ANOA })\}]}\end{array}$ & 0.3125 & 0.3125 & 0.3125 & 0.3125 & 0.3125 & 0.3125 \\
\hline
\end{tabular}

\# Assuming opening NOA = Rs. 2,80,000.

TABLE 5 : OASP ' B'

\begin{tabular}{|c|c|c|c|c|c|c|}
\hline \multirow[b]{2}{*}{ Particulars } & \multicolumn{5}{|c|}{ Future Business Scenarios } & \multirow{3}{*}{$\begin{array}{c}\text { Expected } \\
\text { Value }\end{array}$} \\
\hline & $\begin{array}{l}\text { Very } \\
\text { Good }\end{array}$ & Good & Normal & Bad & Very Bad & \\
\hline Probability & 0.10 & 0.15 & 0.45 & 0.25 & 0.05 & \\
\hline NOA [Rs. ] & $3,60,000$ & $3,60,000$ & $3,60,000$ & $3,60,000$ & $3,60,000$ & $3,60,000$ \\
\hline s [ Rs. ] & 20.00 & 20.00 & 20.00 & 20.00 & 20.00 & 20.00 \\
\hline $\mathrm{v}^{@} \quad[$ Rs. $]$ & 10.00 & 10.00 & 10.00 & 10.00 & 10.00 & 10.00 \\
\hline $\mathrm{c}\{=(\mathrm{s}-\mathrm{v})\}[\mathrm{Rs}]$. & 10.00 & 10.00 & 10.00 & 10.00 & 10.00 & 10.00 \\
\hline $\mathrm{r}\{=(\mathrm{c} / \mathrm{s})\}$ & 0.5 & 0.5 & 0.5 & 0.5 & 0.5 & 0.5 \\
\hline $\mathrm{V}\{=(\mathrm{v} * \mathrm{q})\}[\mathrm{Rs}]$. & $1,80,000$ & $1,40,000$ & $1,00,000$ & 60,000 & 20,000 & $1,00,000$ \\
\hline $\mathrm{F}^{@} \quad[$ Rs. $]$ & 60,000 & 60,000 & 60,000 & 60,000 & 60,000 & 60,000 \\
\hline $\mathrm{T}\{=(\mathrm{V}+\mathrm{F})\}[\mathrm{Rs}]$. & $2,40,000$ & $2,00,000$ & $1,60,000$ & $1,20,000$ & 80,000 & $1,60,000$ \\
\hline $\mathrm{S}\{=(\mathrm{s} * \mathrm{q})\}[$ Rs. $]$ & $3,60,000$ & $2,80,000$ & $2,00,000$ & $1,20,000$ & 40,000 & $2,00,000$ \\
\hline $\mathrm{C}\{=(\mathrm{c} * \mathrm{q})\}[\mathrm{Rs}]$. & $1,80,000$ & $1,40,000$ & $1,00,000$ & 60,000 & 20,000 & $1,00,000$ \\
\hline $\mathrm{OE}\{=(\mathrm{C}-\mathrm{F})\}[\mathrm{Rs}]$. & $1,20,000$ & 80,000 & 40,000 & 0 & $(-) 40,000$ & 40,000 \\
\hline ANOA $^{\#}[$ Rs. ] & $3,20,000$ & $3,20,000$ & $3,20,000$ & $3,20,000$ & $3,20,000$ & $3,20,000$ \\
\hline $\begin{array}{c}\text { NOATR } \\
\{=(\mathrm{S} / \text { ANOA })\} \\
{[\text { times }]}\end{array}$ & 1.125 & 0.875 & 0.625 & 0.375 & 0.125 & 0.625 \\
\hline
\end{tabular}


Operating Leverage Analysis - A Conceptual Framework

TABLE 5 : OASP ' $B$ ' ( continued )

\begin{tabular}{|c|c|c|c|c|c|c|}
\hline \multirow[b]{2}{*}{ Particulars } & \multicolumn{3}{|c|}{ Future Business } & \multicolumn{2}{|l|}{ Scenarios } & \multirow[b]{2}{*}{$\begin{array}{c}\text { Expected } \\
\text { Value }\end{array}$} \\
\hline & $\begin{array}{l}\text { Very } \\
\text { Good }\end{array}$ & Good & Normal & Bad & Very Bad & \\
\hline$\left\{\begin{array}{c}\text { RONOA } \\
(\text { OE } / \text { ANOA })\} \\
* 100 \%\end{array}\right.$ & 37.5 & 25 & 12.5 & 0 & (-) 12.5 & 12.5 \\
\hline $\mathrm{b}_{(\mathrm{q})}\{=(\mathrm{F} / \mathrm{c})\}[$ units $]$ & 6,000 & 6,000 & 6,000 & 6,000 & 6,000 & 6,000 \\
\hline $\mathrm{b}_{(\mathrm{s})}\{=(\mathrm{F} / \mathrm{r})\}[$ Rs. $]$ & $1,20,000$ & $1,20,000$ & $1,20,000$ & $1,20,000$ & $1,20,000$ & $1,20,000$ \\
\hline $\begin{array}{c}\mathrm{b}_{(\text {NOATR })} \\
{[=\{\mathrm{F} /(\mathrm{r} * \text { ANOA })\}]}\end{array}$ & 0.375 & 0.375 & 0.375 & 0.375 & 0.375 & 0.375 \\
\hline
\end{tabular}

@ ' $v$ ' or ' $F$ ' for OASP ' $B$ ' are calculated vide eqs. (56) or (57), based on the related values for OASP ' $A$ ', so that $E(T)$ are the same in case of the two OASPs.

\# Assuming opening NOA = Rs. 2,80,000.

The Coefficient of Variation (CV) and Mean Absolute Deviation (MAD) of S , OE NOATR and RONOA in respect of the two OASPs are calculated below:

TABLE 6 : CV ( S ) and MAD ( S ) for OASP s ' $A$ ' $\&$ ' $B$ '

\begin{tabular}{|c|c|c|c|}
\hline $\begin{array}{c}\text { Business } \\
\text { Scenarios }\end{array}$ & $\begin{array}{c}\text { Probability } \\
\left(\mathrm{p}_{\mathrm{m}}\right)\end{array}$ & $\left|\mathrm{S}_{\mathrm{m}}-\mathrm{E}(\mathrm{S})\right| * \mathrm{p}_{\mathrm{m}}$ & $\left\{\mathrm{S}_{\mathrm{m}}-\mathrm{E}(\mathrm{S})\right\}^{2} * \mathrm{p}_{\mathrm{m}}$ \\
\hline & & Rs. & Rs. ( million ) \\
\hline Very Good & 0.10 & 16,000 & 2,560 \\
\hline Good & 0.15 & 12,000 & 060 \\
\hline Normal & 0.45 & 0 & 0 \\
\hline Bad & 0.25 & 20,000 & 1,600 \\
\hline Very Bad & 0.05 & 8,000 & $\boldsymbol{\sigma}_{\text {OE }}=$ Rs. 6,400 million \\
\hline & & MAD ( OE $)=$ Rs. 56,000 & $\boldsymbol{\sigma}_{\text {OE }}=\mathbf{R s . 8 0 , 0 0 0}$ \\
\hline & & $\mathbf{C V}(\mathbf{O E})=\mathbf{0 . 4}$ & \multicolumn{2}{c}{} \\
\hline
\end{tabular}

TABLE 7 : $\mathrm{CV}$ ( OE ) and MAD (OE) for OASP ' $A$ '

\begin{tabular}{|c|c|c|c|}
\hline $\begin{array}{c}\text { Business } \\
\text { Scenarios }\end{array}$ & $\begin{array}{c}\text { Probability } \\
\left(\mathrm{p}_{\mathrm{m}}\right)\end{array}$ & $\left|\mathrm{OE}_{\mathrm{m}}-\mathrm{E}(\mathrm{OE})\right| * \mathrm{p}_{\mathrm{m}}$ & $\left\{\mathrm{OE}_{\mathrm{m}}-\mathrm{E}(\mathrm{OE})\right\}^{2} * \mathrm{p}_{\mathrm{m}}$ \\
\hline Very Good & 0.10 & Rs. & Rs. ( million $)$ \\
\hline Good & 0.15 & 6,400 & 409.6 \\
\hline Normal & 0.45 & 4,800 & 153.6 \\
\hline Bad & 0.25 & 0 & 0 \\
\hline Very Bad & 0.05 & 8,000 & 256.0 \\
\hline & & MAD ( OE $)=$ Rs. 22,400 & $\boldsymbol{\sigma}_{\text {OE }}^{2}$ Rs. 1,024 million \\
\hline & & CV ( OE $)=\mathbf{0 . 8}$ & $\boldsymbol{\sigma}_{\text {OE }}=\mathbf{R s . ~ 3 2 , 0 0 0}$ \\
\hline
\end{tabular}

TABLE 8: CV (NOATR) and MAD (NOATR) for OASP s ' A' \& ' B'

\begin{tabular}{|c|c|c|c|}
\hline $\begin{array}{c}\text { Business } \\
\text { Scenarios }\end{array}$ & $\begin{array}{c}\text { Probability } \\
\left(\mathrm{p}_{\mathrm{m}}\right)\end{array}$ & $\mid$ NOATR $_{\mathrm{m}}-\mathrm{E}($ NOATR $) \mid * \mathrm{p}_{\mathrm{m}}$ & $\left\{\text { NOATR }_{\mathrm{m}}-\mathrm{E}(\text { NOATR })\right\}^{2} * \mathrm{p}_{\mathrm{m}}$ \\
\hline & & times & Times \\
\hline Very Good & 0.10 & 0.05 & 0.025 \\
\hline Good & 0.15 & 0.0375 & 0.009375 \\
\hline Normal & 0.45 & 0 & 0.015625 \\
\hline Bad & 0.25 & 0.0625 & 0.0125 \\
\hline Very Bad & 0.05 & 0.025 & $\boldsymbol{\sigma}_{\text {NOATR }}=\mathbf{0 . 0 6 2 5}$ times \\
\hline & & MAD ( NOATR $)=\mathbf{0 . 1 7 5}$ times & $\boldsymbol{\sigma}_{\text {NOATR }}=\mathbf{0 . 2 5}$ times \\
\hline & & CV ( NOATR $)=\mathbf{0 . 4}$ & \\
\hline
\end{tabular}


TABLE 9 : CV ( RONOA) and MAD ( RONOA) for OASP 'A'

\begin{tabular}{|c|c|c|c|}
\hline $\begin{array}{c}\text { Business } \\
\text { Scenarios }\end{array}$ & $\begin{array}{c}\text { Probability } \\
\left(\mathrm{p}_{\mathrm{m}}\right)\end{array}$ & $\mid$ RONOA $_{\mathrm{m}}-\mathrm{E}($ RONOA $) \mid * \mathrm{p}_{\mathrm{m}}$ & $\left\{\text { RONOA }_{\mathrm{m}}-\mathrm{E}(\mathrm{RONOA})\right\}^{2} * \mathrm{p}_{\mathrm{m}}$ \\
\hline Very Good & 0.10 & $\%$ & $\%$ \\
\hline Good & 0.15 & 1.5 & 40 \\
\hline Normal & 0.45 & 0 & 0 \\
\hline Bad & 0.25 & 2.5 & 25 \\
\hline Very Bad & 0.05 & 1 & $\boldsymbol{\sigma}_{\text {RONOA }}^{2} \mathbf{1 0 0} \%$ \\
\hline & & MAD ( RONOA $)=\mathbf{7 \%}$ & $\boldsymbol{\sigma}_{\text {RONOA }}=\mathbf{1 0} \%$ \\
\hline & & CV ( RONOA $)=\mathbf{0 . 8}$ &
\end{tabular}

TABLE 10: CV ( OE) and MAD ( OE ) for OASP ' $B$ '

\begin{tabular}{|c|c|c|c|}
\hline $\begin{array}{c}\text { Business } \\
\text { Scenarios }\end{array}$ & $\begin{array}{c}\text { Probability } \\
\left(\mathrm{p}_{\mathrm{m}}\right)\end{array}$ & $\left|\mathrm{OE}_{\mathrm{m}}-\mathrm{E}(\mathrm{OE})\right| * \mathrm{p}_{\mathrm{m}}$ & $\left\{\mathrm{OE}_{\mathrm{m}}-\mathrm{E}(\mathrm{OE})\right\}^{2} * \mathrm{p}_{\mathrm{m}}$ \\
\hline Very Good & 0.10 & Rs. & Rs. ( million ) \\
\hline Good & 0.15 & 8,000 & 640 \\
\hline Normal & 0.45 & 6,000 & 0 \\
\hline Bad & 0.25 & 0,000 & 300 \\
\hline Very Bad & 0.05 & 4,000 & 320 \\
\hline & & MAD ( OE $)=$ Rs. 28,000 & $\boldsymbol{\sigma}_{\text {OE }}^{\mathbf{2}}=$ Rs. 1,600 million \\
\hline & & CV ( OE ) $=\mathbf{1}$ & $\boldsymbol{\sigma}_{\text {OE }}=$ Rs. 40,000 \\
\hline
\end{tabular}

TABLE 11 : CV ( RONOA) and MAD ( RONOA ) for OASP ' B'

\begin{tabular}{|c|c|c|c|}
\hline $\begin{array}{l}\text { Business } \\
\text { Scenarios }\end{array}$ & $\begin{array}{c}\text { Probability } \\
\left(\mathrm{p}_{\mathrm{m}}\right)\end{array}$ & $\left|\mathrm{RONOA}_{\mathrm{m}}-\mathrm{E}(\mathrm{RONOA})\right|^{*} \mathrm{p}_{\mathrm{m}}$ & $\left\{\text { RONOA }_{\mathrm{m}}-\mathrm{E}(\mathrm{RONOA})\right\}^{2} * \mathrm{p}_{\mathrm{m}}$ \\
\hline & & $\%$ & $\%$ \\
\hline Very Good & 0.10 & 2.5 & 62.5 \\
\hline Good & 0.15 & 1.875 & 23.4375 \\
\hline Normal & 0.45 & 0 & 0 \\
\hline $\mathrm{Bad}$ & 0.25 & 3.125 & 39.0625 \\
\hline Very Bad & 0.05 & 1.25 & 31.25 \\
\hline & & MAD $($ RONOA $)=8.75 \%$ & $\sigma_{\text {RONOA }}^{2}=156.25 \%$ \\
\hline & & CV $($ RONOA $)=1$ & $\sigma_{\mathrm{RONOA}}=12.5 \%$ \\
\hline
\end{tabular}

TABLE 12 : Calculation of DÕ $\mathbf{L}_{E}$

\begin{tabular}{|c|c|c|}
\hline Particulars & OASP 'A', & OASP ' B' \\
\hline Dõ $\mathbf{L}_{\mathbf{S}}[=\{\mathrm{E}(\mathrm{F}) / \mathrm{E}(\mathrm{V})\}]$ & $(1 / 3)$ or 0.33 & 0.6 \\
\hline 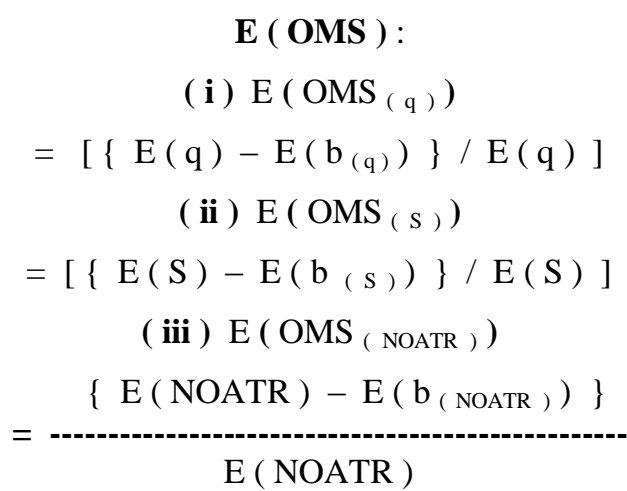 & 0.5 & 0.4 \\
\hline
\end{tabular}


TABLE 12 : Calculation of DÕL ${ }_{E}$ ( continued )

\begin{tabular}{|c|c|c|}
\hline Particulars & OASP ' ${ }^{\prime}{ }^{\prime}$ & OASP ' B' \\
\hline 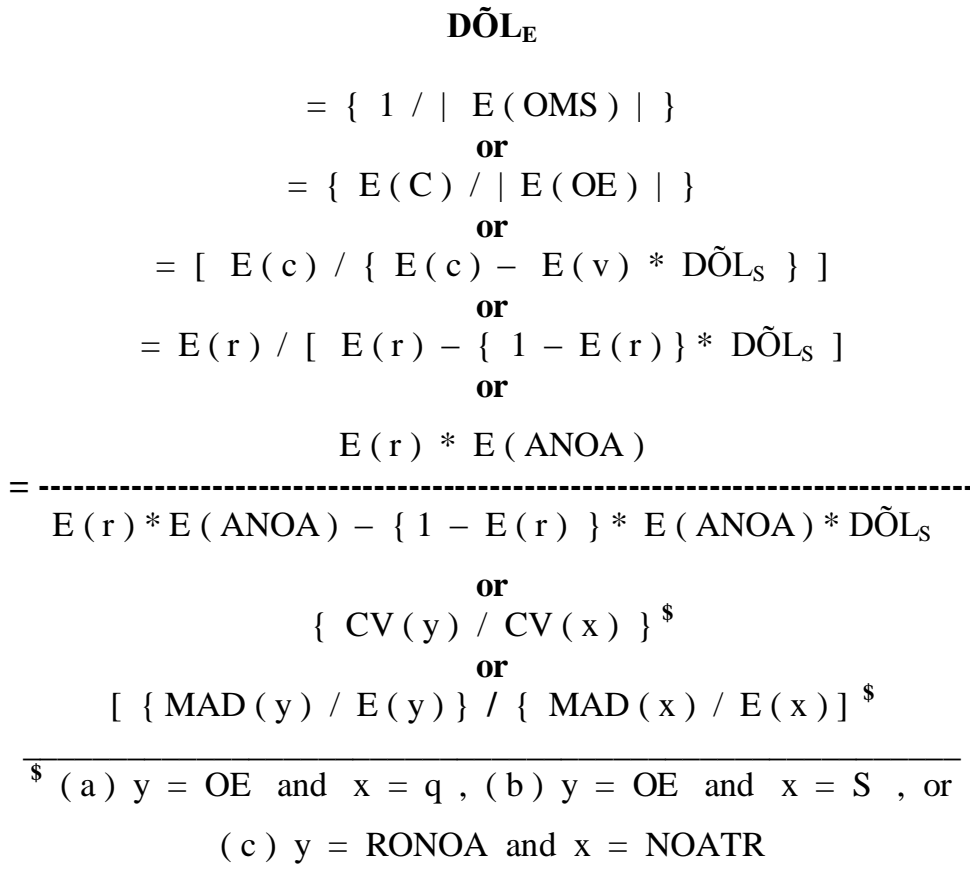 & 2 & 2.5 \\
\hline
\end{tabular}

Now, the conditions for the existence and non - existence of the operating leverage effect in respect of the two OASP s may be summarized as follows :

TABLE 13 : Conditions for existence and non-existence of the operating leverage effect

\begin{tabular}{|c|c|c|}
\hline OASP & $\begin{array}{c}\text { Operating leverage effect will exist } \\
{\left[\text { i.e. DÕLE } L_{E} 1 \text { ] when : }\right.}\end{array}$ & $\begin{array}{c}\text { Operating leverage effect will not } \\
\text { exist [ i.e. DÕ } L_{E}<1 \text { ] when : }\end{array}$ \\
\hline ' $\mathbf{A}$ ' & $\begin{array}{l}\text { (a) } 2,500 \text { units }<\mathrm{E}(\mathrm{q})<5,000 \text { units } \\
\text { or } \mathrm{E}(\mathrm{q})>5,000 \text { units } \\
\text { (b) } \mathrm{Rs.} 50,000<\mathrm{E}(\mathrm{S})<\mathrm{Rs} .1,00,000 \\
\text { or } \mathrm{E}(\mathrm{S})>\text { Rs. } 1,00,000 \\
\text { (c) } 0.15625 \text { times }<\mathrm{E}(\mathrm{NOATR})<0.3125 \text { times } \\
\text { or } \mathrm{E}(\mathrm{NOATR})>0.3125 \text { times } \\
\text { (d) } 0<\mathrm{DO} \mathrm{L}_{\mathrm{S}}<(2 / 3) \\
\text { or }(2 / 3)<\mathrm{DOL}_{\mathrm{S}}<(4 / 3)\end{array}$ & 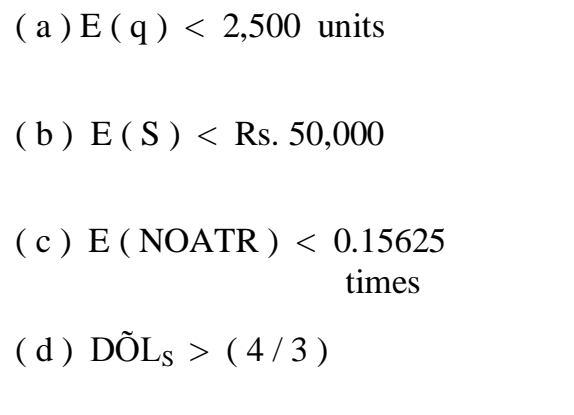 \\
\hline ' B' & $\begin{array}{l}\text { (a) } 3,000 \text { units }<\mathrm{E}(\mathrm{q})<6,000 \text { units } \\
\text { or } \mathrm{E}(\mathrm{q})>6,000 \text { units } \\
\text { (b) } \text { Rs. } 60,000<\mathrm{E}(\mathrm{S})<\mathrm{Rs.} 1,20,000 \\
\text { or } \mathrm{E}(\mathrm{S})>\text { Rs. } 1,20,000 \\
\text { (c) } 0.1875 \text { times }<\mathrm{E}(\text { NOATR })<0.375 \text { times } \\
\text { or } \mathrm{E}(\text { NOATR })>0.375 \text { times } \\
\text { (d) } 0<\mathrm{DO}_{\mathrm{S}}<1 \\
\text { or } 1<\mathrm{DO}_{\mathrm{S}}<2\end{array}$ & $\begin{array}{l}\text { (a ) } E(\text { q })<3,000 \text { units } \\
\text { (b ) } E(S)<\text { Rs. } 60,000 \\
\text { (c) } E(\text { NOATR })<0.1875 \text { times } \\
\text { (d ) DÕL } L_{S}>2\end{array}$ \\
\hline
\end{tabular}


Let us now consider the process of decision-making for the choice between the two alternative OASPs considering $\mathrm{q}$ and $\mathrm{OE}$ as the IFV and the DFV respectively.

Assuming that the degrees of DOLR averseness and UOLR affinity subjectively assigned by the decision-maker are $80 \%$ and $20 \%$ respectively, the linear utility functions of DÕ $\mathrm{L}_{\mathrm{E}}$ for DOLR and UOLR scenarios and the expected value of utility (or disutility) of DÕ $\mathrm{L}_{\mathrm{E}}$ in respect of the two OASPs may be given from eqs. (51), (52) and (53) and the probability distribution of $\mathrm{OE}\{$ same as the probability distribution of $\mathrm{q}\}$ as follows :

( 1 ) OASP ' A'

$\mathrm{U}\left(\mathrm{DO} \mathrm{L}_{\mathrm{E}[\text { DOLR }]}\right)=(-)\{(0.8 / 0.2) * 2\}=(-) 8$ utils .

$\mathrm{U}\left(\mathrm{DÕL} \mathrm{L}_{\mathrm{E}[\text { UOLR }]}\right)=(0.2 / 0.8) * 2=0.5$ utils .

$\mathrm{E}\left(\mathrm{U}\left(\mathrm{DO} \mathrm{L}_{\mathrm{E}}\right)\right)=(-) 8 * 0.3+0.5 * 0.7=(-) 2.05$ utils .

$[\mathrm{P}(\mathrm{DOLR})=\mathrm{P}(\mathrm{OE}<\mathrm{E}(\mathrm{OE}))=\mathrm{P}(\mathrm{q}<\mathrm{E}(\mathrm{q}))=0.25+0.05=0.3$

$\mathrm{P}(\mathrm{UOLR})=\mathrm{P}(\mathrm{OE} \geq \mathrm{E}(\mathrm{OE}))=\mathrm{P}(\mathrm{q} \geq \mathrm{E}(\mathrm{q}))=0.10+0.15+0.45=0.7]$

( 2 ) OASP ' $B$ '

$\mathrm{U}\left(\mathrm{DÕL} \mathrm{L}_{\mathrm{E} \text { [ DOLR }]}\right)=(-)\{(0.8 / 0.2) * 2.5\}=(-) 10$ utils .

$\mathrm{U}\left(\mathrm{DO} \mathrm{L}_{\mathrm{E}[\text { UOLR }]}\right)=(0.2 / 0.8) * 2.5=0.625$ utils .

$\mathrm{E}\left(\mathrm{U}\left(\mathrm{DO} \mathrm{L}_{\mathrm{E}}\right)\right)=(-) 10 * 0.3+0.625 * 0.7=(-) 2.5625$ utils

$[\mathrm{P}(\mathrm{DOLR})=\mathrm{P}(\mathrm{OE}<\mathrm{E}(\mathrm{OE}))=\mathrm{P}(\mathrm{q}<\mathrm{E}(\mathrm{q}))=0.25+0.05=0.3$

$\mathrm{P}(\mathrm{UOLR})=\mathrm{P}(\mathrm{OE} \geq \mathrm{E}(\mathrm{OE}))=\mathrm{P}(\mathrm{q} \geq \mathrm{E}(\mathrm{q}))=0.10+0.15+0.45=0.7]$

Hence, the decision-maker will choose OASP ' $A$ ' yielding the lower value of

$\left|\mathrm{E}\left(\mathrm{U}\left(\mathrm{DO} \mathrm{L}_{\mathrm{E}}\right)\right)\right|\{2.05$ utils $<2.5625$ utils $\}$ based on the principle of minimization of the absolute value of expected disutility ( negative utility).

[ Notes:

(1) If the decision-maker is assumed to assign $40 \%$ as the degree of DOLR averseness (and hence $60 \%$ as the degree of UOLR affinity), then $E\left(U\left(D O L_{E}\right)\right)$ for the two OASP $s$ will be given as :

$E\left(U\left(D \tilde{O} L_{E}\right)\right)_{A}=(-)\{(0.4 / 0.6) * 2 * 0.3\}+(0.6 / 0.4) * 2 * 0.7=2.5$ utils ;

$E\left(U\left(D \tilde{O} L_{E}\right)\right)_{B}=(-)\{(0.4 / 0.6) * 2.5 * 0.3\}+(0.6 / 0.4) * 2.5 * 0.7=3.125$ utils ;

and OASP' $B$ ' yielding the higher value of $E\left(U\left(D \tilde{O} L_{E}\right)\right)$ based on the principle of maximization of expected utility will be chosen.

(2) If the decision-maker is assumed to assign $50 \%$ as the degree of DOLR averseness (and hence $50 \%$ as the degree of UOLR affinity), then $E\left(U\left(D O \tilde{L} L_{E}\right)\right)$ for the two OASP $s$ will be given as :

$E\left(U\left(D \tilde{O} L_{E}\right)\right)_{A}=(-)(2 * 0.3)+2 * 0.7=0.8$ util ;

$E\left(U\left(D \tilde{O} L_{E}\right)\right)_{B}=(-)(2.5 * 0.3)+2.5 * 0.7=1$ util ;

and $O A S P$ ' $B$ ' yielding the higher value of $E\left(U\left(D \tilde{O} L_{E}\right)\right)$ will be chosen.]

\section{( II ) EX - POST OPERATING LEVERAGE ANALYSIS}

Considering that the decision-maker has chosen OASP ' $A$ ', let us now assume that, at the end of the short - run planning horizon, given the actual value of $\mathrm{q}\{\mathrm{A}(\mathrm{q})\}$, the revised expected values of $\mathrm{S}, \mathrm{C}$ and $\mathrm{OE}$, ceteris paribus $[\mathrm{E}(\mathrm{s}), \mathrm{E}(\mathrm{v}), \mathrm{E}(\mathrm{c}), \mathrm{E}(\mathrm{F})$ and $\mathrm{E}(\mathrm{ANOA})$ remaining constant ] and ex-post DOL , under two actual business scenarios I and II are obtained as follows :

TABLE 14: Calculation of ex - post DOL $_{E}$

\begin{tabular}{|c|c|c|}
\hline Particulars & Scenario I & Scenario II \\
\hline $\mathrm{E}(\mathrm{s})$ & Rs. 20.00 & Rs. 20.00 \\
\hline $\mathrm{E}(\mathrm{c})$ & Rs. 8.00 & Rs. 8.00 \\
\hline$E(F)$ & Rs. 40,000 & Rs. 40,000 \\
\hline $\mathrm{E}(\mathrm{ANOA})$ & Rs. $3,20,000$ & Rs. $3,20,000$ \\
\hline$A(q)$ & 4,000 units & 13,000 units \\
\hline $\operatorname{RE}(S)[=\{E(s) * A(q)\}]$ & Rs. 80,000 & Rs. $2,60,000$ \\
\hline $\operatorname{RE}(\mathrm{C})[=\{\mathrm{E}(\mathrm{c}) * \mathrm{~A}(\mathrm{q})\}]$ & Rs. 32,000 & Rs. $1,04,000$ \\
\hline $\operatorname{RE}(\mathrm{OE})[=\{\operatorname{RE}(\mathrm{C})-\mathrm{E}(\mathrm{F})\}]$ & ( - ) Rs. 8,000 & Rs. 64,000 \\
\hline$|\mathrm{RE}(\mathrm{OE})|$ & Rs. 8,000 & Rs. 64,000 \\
\hline $\operatorname{RE}($ NOATR $)[=\{\operatorname{RE}(S) / E($ ANOA $)]$ & 0.25 times & 0.8125 times \\
\hline $\operatorname{RE}(\mathrm{RONOA})[=\{\operatorname{RE}(\mathrm{OE}) / \mathrm{E}(\mathrm{ANOA})]$ & $(-) 2.5 \%$ & $20 \%$ \\
\hline DÓL $_{\mathbf{E}}[=\{\operatorname{RE}(\mathrm{C}) /|\operatorname{RE}(\mathrm{OE})|\}]$ & 4 & 1.625 \\
\hline
\end{tabular}


For DÕ $L_{E}=2$, the Operating Leverage Efficiency ( OLE ) is calculated for the two actual scenarios as follows :

( 1 ) Scenario I [ vide eq. ( 66$)$ ] : OLE $=(2 / 4) * 100 \%=50 \%$.

( 2 ) Scenario II [ vide eq. ( 67$)$ ] : OLE $=(1.625 / 2) * 100 \%=81.25 \%$.

\section{Conclusion :}

The intra - firm analysis of operating leverage based on the mechanical analysis of physical leverage (the genesis of the concept of operating leverage) is thus composed of : ( a ) ex - ante operating leverage analysis conducted at the beginning of a short-run planning horizon for choosing an 'Operating Account Structural Plan' (OASP) from alternative OASPs based on the principle of maximization of expected utility \{ or the principle of minimization of the absolute value of expected disutility (negative utility) $\}$ of ex - ante DOLE , considering the degrees of 'Downside Operating Leverage Risk (DOLR) averseness ' and 'Upside Operating Leverage Risk (UOLR) affinity' subjectively assigned by the decision - maker, and ( b ) ex - post analysis conducted at the end of the planning horizon for the performance appraisal of the decision-maker based on operating leverage efficiency . The analysis of operating leverage may be further extended in the case of a multiple products manufacturing firm and (or) also in the case of the existence of imperfect competition in the input and output markets $\{$ yielding non - linear functional relationship between sales (quantity or value ) and $\mathrm{OE}$.

\section{References}

[1] Brigham, E. F. and J.F. Houston ( 2001 ), Fundamentals of Financial Management, Harcourt Asia

[2] Chandra, P. ( 2001 ), Financial Management - Theory and Practice, Tata McGraw - Hill .

[3] Gitman, L .J. , M. D. Joehnk and G. E. Pinches ( 1985 ), Managerial Finance, Harper \& Row.

[4] Gitman L. J. (2006), Principles of Managerial Finance, Pearson Education .

[5] Horngren, C.T., S.M. Datar, G. Foster, M.V. Rajan and C. Ittner ( 2009), Cost Accounting: A Managerial Emphasis, Pearson Education / Dorling Kinderley (India ).

[6] Knight, F. H. ( 2006 ) [ originally published in 1921], Risk, Uncertainty and Profit, Cosimo Inc.

[7] Lee, A.C., J .C. Lee and C.F. Lee ( 2009), Financial Analysis, Planning \& Forecasting , World Scientific / Cambridge University Press India.

[8] Peterson, M. ( 2009 ), An Introduction to Decision Theory, Cambridge University Press.

[9] Ram, Tripathi, Goyal and Gupta ( 1986 ), Concise Physics - I .C. S. E , Selina Publishers .

[10] Samuelson, W.F. and S.G. Marks ( 2008 ), Managerial Economics, John Wiley \& Sons / Wiley - India .

[11] Sinha,S.(2010), Corporate Leverage - Revisited, Self - published ( powered by www.pothi.com ) by author . Retrieved on 16.12.2011 from http://papers.ssrn.com/sol3/papers.cfm?abstract_id=1714390 . 